\title{
Sustainability Dimensions Assessment in Four Traditional Agricultural Systems in the Amazon
}

\section{OPEN ACCESS}

Edited by:

Tapan Kumar Nath,

University of Nottingham Malaysia

Campus, Malaysia

Reviewed by:

Gabriel da Silva Medina,

University of Brasilia, Brazil

Ajit Singh,

University of Nottingham Malaysia

Campus, Malaysia

*Correspondence:

Marco Heredia- $R$

mageher@gmail.com

TORCID:

Liette Vasseur

orcid.org/0000-0001-7289-2675

Bolier Torres

orcid.org/0000-0002-9182-419X

Marco Heredia- $R$

orcid.org/0000-0002-6039-3411

Deniz Barreto

orcid.org/0000-0003-0000-5162

Carlos G. H. Díaz-Ambrona

orcid.org/0000-0003-1452-8757

Specialty section:

This article was submitted to Land, Livelihoods and Food Security, a section of the journal

Frontiers in Sustainable Food Systems

Received: 24 September 2021 Accepted: 17 December 2021

Published: 25 January 2022

Citation:

Heredia-R M, Torres B, Vasseur L, Puhl L, Barreto $D$ and

Díaz-Ambrona CGH (2022)

Sustainability Dimensions Assessment in Four Traditional Agricultural

Systems in the Amazon.

Front. Sustain. Food Syst. 5:782633.

doi: 10.3389/fsufs.2021.782633

\author{
Marco Heredia- $R^{1,2 * t}$, Bolier Torres ${ }^{3,4 t}$, Liette Vasseur ${ }^{5 \dagger}$, Laura Puhl ${ }^{6}$, Deniz Barreto ${ }^{4 \dagger}$ and \\ Carlos G. H. Díaz-Ambrona ${ }^{1+}$
}

\begin{abstract}
${ }^{1}$ AgSystems, Ceigram, itdUPM, Centro de Innovación en Tecnología para el Desarrollo, Universidad Politécnica de Madrid (UPM), Madrid, Spain, ${ }^{2}$ Facultad de Ciencias Agropecuarias, Universidad Técnica Estatal de Quevedo (UTEQ), Quevedo, Ecuador, ${ }^{3}$ Departamento de Ciencias de la Vida, Universidad Estatal Amazónica (UEA), Puyo, Ecuador, ${ }^{4}$ Corporation for Sustainable Development, Conservation and Climate Change, Tena, Ecuador, ${ }^{5}$ Department of Biological Sciences, Faculty of Math and Science, United Nations Educational Scientific and Cultural Organization (UNESCO) Chair on Community Sustainability, Brock University, St. Catharines, ON, Canada, ${ }^{6}$ Departamento de Métodos Cuantitativos y Sistemas de Información, Facultad de Agronomía, Universidad de Buenos Aires, Buenos Aires, Argentina
\end{abstract}

Although traditional agriculture carried out by ethnic groups is considered for its high biodiversity and important for food security and sovereignty, few studies have investigated the potential of these systems in the interest of promoting a sustainable agricultural development policy according to United Nations Sustainable Development Goals. Using the FAO's Sustainability Assessment of Food and Agriculture (SAFA) methodology, this study analyzed the sustainability of four traditional agricultural systems, three indigenous (Waorani, Shuar, and Kichwa) and one migrant settler populations in the Yasuní Biosphere Reserve (YBR) and identified synergies and trade-offs among the dimensions of sustainability. The results showed different dynamics in all dimensions of sustainability-specifically, trade-offs in the dimensions of good governance with environmental integrity and social well-being, economic resilience, and social well-being. It was identified that the differences in terms of sustainability are narrowing between the indigenous Shuar people's traditional agricultural systems and those of migrant settlers, which provides policymakers with specific information to design sustainable development policies and rescue traditional agricultural systems in the Amazon region.

Keywords: agriculture, indigenous peoples, migrant settlers, rural development, Yasuni Biosphere Reserve, livelihoods

\section{INTRODUCTION}

Traditional production systems have several attributes that contribute to sustainable development, such as high species diversity with strong environmental adaptability (Zhang et al., 2011) and resistance to pests and diseases (Flores-Delgadillo et al., 2011). They can act as instruments for resilience, mitigation, and adaptation to climate change (McCord et al., 2015; Torres et al., 2015, 2018; Tesfaye and Tirivayi, 2020). Such systems can help manage risk and decrease rural poverty and food insecurity (Michler and Josephson, 2017; Waha et al., 2018; Lovo and Veronesi, 2019; Mustafa et al., 2019; Bellon et al., 2020) through providing income from local markets (Bellon et al., 2020) and nutrition and child health in impoverished rural households. Due to the great diversity of edible and commercial crop species (Perreault, 2005), traditional production systems 
have been supporting many indigenous populations who live in voluntary collective isolation. To protect the sustainability of these systems, instruments are needed to reduce the possibility to have these communities becoming or being forced to be in contact with the outside world (Cabodevilla, 2008; Beckerman et al., 2009; United Nations, 2009; Colleoni and Proaño, 2010; Heredia-R and Hernández, 2019), based on these antecedents, Intergovernmental Platform on Biodiversity and Ecosystem Services (IPBES; http://www.ipbes.net/) and the Convention on Biological Diversity (CBD) recognizes that the diverse social, cultural and environmental knowledge of indigenous peoples and local communities (IPLC) contributes extensively to sustainability across large parts of the globe, and thus has a major role to play in assessments and policy formulation for biodiversity and ecosystem services (IPBES, 2012; Tengö et al., 2017; Hill et al., 2020).

The Ecuadorian Amazon Region (EAR) is home to 11 Indigenous groups who have inhabited the land for thousands of years. Sixty years ago, several populations of migrant settlers arrived after the discovery of significant oil reserves in the northern EAR. Roads were opened by oil companies (Pichón, 1997; Bilsborrow et al., 2004), leading to a change in the demography with populations of heterogeneous life strategies (Torres et al., 2018). The northern EAR has become a multiethnic and multicultural system. Within this region, the Yasuní Biosphere Reserve is populated by Indigenous Waorani, Shuar, and Kichwa people as well as migrant settlers who arrived mainly from rural areas of the Ecuadorian highlands (Santos, 1996; Murphy et al., 1997; Barbieri et al., 2003, 2009; Bilsborrow et al., 2004; Sellers et al., 2017).

These groups manage their own traditional agricultural systems, which are part of each cultural heritage and geographic origin, for their tangible and intangible assets (Rudel et al., 2002; Lu and Bilsborrow, 2011; Ima Omene, 2012; Torres et al., 2015; Zurita-Benavides, 2017). However, climate variability, deforestation, and poor land management practices have led local populations to depend on agrochemicals (Davis et al., 2012) or in the expansion of the agricultural frontier to increase incomes (Mena et al., 2006, 2011; Walsh et al., 2008). Land use changes and degradation have resulted in the decrease in agricultural sustainability as a means of livelihood. Agricultural intensification policies, migration processes, population growth, and low educational levels (Viteri-Salazar and Toledo, 2020) have led to socioeconomic and demographic changes that include alterations in household composition and other family life cycle factors (Bilsborrow et al., 2004). It is necessary to analyze these factors from a sustainability perspective to gradually define potential solution for the future under the 2030 Sustainable Development Goals.

The sustainability of traditional production systems in the Amazon has generally been assessed from an environmental perspective (Galford et al., 2013). Nevertheless, social, economic, and governance dimensions of sustainability are also important, but little studied in this region (SAFA, 2012). Sustainability assessment aims to better understand the conditions of a location (from a community or region to a country) to support future decisions making that support all three pillars, i.e., social, economic, and environmental, of sustainable development (Bond et al., 2012). Several approaches have been developed including (Belcher et al., 2004) the human well-being index (Kaivo-oja et al., 2014), the environmental performance index (Hsu and Zomer, 2014), and the sustainable development index (BarreraRoldán and Saldívar-Valdés, 2002). A multicriteria approach is often encouraged to ensure that the social component is not forgotten (Maness and Farrell, 2004). This is especially important when examining sustainability in the context of resource management and therefore agricultural development (Asimeh et al., 2020). For traditional production systems, such assessment provides not only benchmarks but also help reveal the impacts of policy measures adopted at a national level on a region or individual farm (Van Calker et al., 2005).

Sustainability assessments require a combination of methods and models to provide useful information on the impacts of past or proposed changes within systems (Thornton and Herrero, 2001). No single approach can satisfy the multiple purposes of sustainability assessment (Schader et al., 2014). Generally, the results of sustainability assessment are a starting point for discussion, reflection, and learning (De Olde et al., 2016). Within this context, our study seeks to: (a) examine the main agricultural and socio-demographic characteristics at the household level in four social groups (Waorani, Shuar, Kichwa, and migrant settlers) living in the YBR; (b) evaluate the sustainability dimensions of their traditional production systems; and (c) identify the existing interactions (synergies and trade-offs) between the sustainability dimensions of these traditional production systems.

\section{The Traditional Agricultural Context of the Waorani, Shuar, Kichwa, and Migrant Settlers in the Yasuni Biosphere Reserve}

The food production system of the Waorani indigenous populations is based on reciprocity or individual production to share with their nuclear families (Rival, 2002), which is complemented by food gathering from the surrounding forests (Tirira et al., 2020). In their language (Wao-terëro), the generic name for the Waorani's traditional production system is the kinkore. According to Zurita-Benavides (2017), this ethnic group considers that the name of the traditional system depends on the main crop, which is usually accompanied with other crop species. For example, if cassava (Manihot esculenta Cranz) is the main crop, it is called kewenkore (a traditional system of cassava production), while if it is banana (Musa paradisiaca), the system is called penenkore (a traditional system of banana production). Likewise, the traditional system based on peanut (Arachis hypogaea) takes the name koromonkore, the one of corn (Zea mays), kaginkore, and the system with barbasco (Lonchocarpus utilis) (a product used for fishing) is called kompankore. These crop systems are generally oriented to subsistence production, with few produces destined for sale. These systems stand out for having a low impact on the landscape and do not use chemical fertilizers or agrochemicals for pest control (Gray and Bilsborrow, 2020). The size of the kinkore depends on the composition of the family group. Edible and medicinal plants are sown, as well as other species that allow for the extraction of 
natural dyes, seeds, and fiber for handicrafts (Zurita-Benavides, 2017). The kinkore are the places where knowledge is transferred to younger generations, commonly managed by Waorani women (Zurita-Benavides, 2017; Paniagua Blanc, 2019).

The Shuar people originate from the southern EAR and migrated to the northern part (Rubenstein, 2001), due to high population growth rate, land scarcity, and low agricultural production (Vasco et al., 2018). Their food supply is obtained through fishing, hunting, gathering forest products (CaballeroSerrano et al., 2017), and growing crops in a traditional system called aja. For the Shuar, the aja is a sacred space and is managed by women (González de Lema and Herrera, 2017). To establish an aja, first the man does the initial clearing of the forest (Karsten et al., 2000), then the woman has the main role of establishing (Pérez-Robalino et al., 2019) and maintaining the aja for life (Pohle and Gerique, 2008), since the aja for this culture constitutes the woman's identity (Carvajal and Shacay, 2004; González de Lema and Herrera, 2017). The transmission of knowledge about the ecology of planting and harvesting is only taught to the daughters (Cañadas and Sandoval, 2019). As the Shuar people have moved into the market economy, they have created an agricultural landscape that is more biodiverse than the mestizo (mixed-race) migrant settler system (Lu and Bilsborrow, 2011), although biodiversity is not as high as the primary forest (Vasco et al., 2017). Therefore, the agricultural practices carried out in an aja are considered compatible with the conservation of biodiversity (Rudel et al., 2002).

The Kichwa population living in the YBR comes from a complex process of multi-ethnic relations between the Quijos, Kichwa from the highlands, Zaparos, Omaguas, Tucanos Shuar, Achuar, Siona, and Secoya (Almeida and Proaño, 2008). This group migrated from Tena and Archidona (Napo, Ecuador) with the opening of roads to the YBR (MAE, 2013). Their predominant traditional production system is the chakra, which today has been widely studied (Torres et al., 2015, 2018; Vera et al., 2017; Coq-Huelva et al., 2018; Vera-Vélez et al., 2019) and is considered a combination of culturally specific means of biosocial construction (Coq-Huelva et al., 2017). It is characterized by its high level of biodiversity (Vera et al., 2017; Vera-Vélez et al., 2019) and a high number of fruit and timber trees (Jadán et al., 2015; Torres et al., 2015; Coq-Huelva et al., 2017, 2018; Luzuriaga-Quichimbo et al., 2019), with the predominant crops being cocoa (Theobroma cacao L.), coffee (Coffea canephora Pierre ex A. Froehner), and to a lesser extent guayusa (Ilex guayusa Loes.) (Krause and Ness, 2017), alongside medicinal plants for healing purposes, spiritual rituals, handicrafts, and consumption (Coq-Huelva et al., 2017).

The traditional production systems of the migrant settlers are more market-oriented and, according to several authors, are less sustainable compared to traditional indigenous systems (Heredia-R et al., 2020a,b,c,d,e; Viteri-Salazar and Toledo, 2020). They include pastures, annual crops (rice, corn, and cassava), and perennial crops (coffee and cacao) to generate income (Mena, 2007; Monteros, 2011), resulting in intense deforestation (Pan and Bilsborrow, 2005; Sellers et al., 2017; Mullan et al., 2018). The dynamics of migrant settlers have forced neighboring indigenous communities to join the market economy and change some of their ancestral traditions of coexistence with the forest (OrtaMartínez and Finer, 2010). Northeastern Ecuador is one of the places where the cattle frontier in Ecuador is rapidly expanding (Sierra, 2000; Suárez et al., 2009), and is one of the main promoters of land-use change and deforestation in the EAR (Sierra, 2013). In this region, as of 2014, it was estimated that around one million hectares of pastureland, which represented $38 \%$ of the total agricultural area in the EAR (MAGAP, 2014), were dedicated to extensive cattle ranching (Lerner et al., 2014). Cattle production is for meat and milk to satisfy both the local demand and national markets (Knoke et al., 2014).

\section{MATERIALS AND METHODS}

\section{Geographical Location}

This study was conducted in the Diversity and Life Zone (DLZ) in the Yasuní Biosphere Reserve (YBR). The YBR was established in 1989 by the Ecuadorian government and has a surface area of 1.68 million hectares. The core conservation area is the Yasuni National Park (YNP), which consists of 9.82 thousand hectares (Taco, 2001; Finer et al., 2009). The DLZ was created in 2007 with the objective of managing in a special way the production systems and livelihoods of indigenous households and migrant settlers established there (Herrera et al., 2017). Through two presidential decrees, the national government declared (1999) and mapped out (2007) a "Forbidden Zone," also called the Intangible Zone or Tagaeri-Taromenane Intangible Zone (ZITT for its Spanish acronym) (Presidencia de la República de Ecuador, 1999, 2007; Pappalardo et al., 2013). The YBR is in the northern part of the Ecuadorian Amazon Region (RAE) and extends between the provinces of Orellana (50.51\%), Pastaza (39.40\%), Napo (8.64\%), Sucumbíos (1.45\%) and it borders two areas of natural and cultural importance: the Sumaco Biosphere Reserve and the Cuyabeno Wildlife Production Reserve (Figure 1).

The YBR is part of an important mosaic of ecosystems. The climate is within the "Amazonian core" (Killeen and Solórzano, 2008), which is characterized by warm temperatures (annual average of $24-27^{\circ} \mathrm{C}$ ), high precipitation (annual average $3,200 \mathrm{~mm}$ ), and high relative humidity (annual average $80-$ 94\%) (Pitman, 2000). The soils are geologically young, fluvial sediments coming from the erosion of the Andes (Pitman et al., 2002; Valencia et al., 2004). The area is part of the hotspot called the "Western Amazon Highlands" (Myers, 1988; Myers et al., 2000). However, like many other areas of high biodiversity, it is threatened by habitat destruction and cultural alterations (Mittermeier et al., 1998; Beristain et al., 2009). The YBR faces high rates of deforestation and land-use change, with one of the main drivers being the opening of roads because of oil concessions (Jorgenson and Coppolillo, 2001; Mena et al., 2006; De la Torre and Cornejo, 2008; Suárez et al., 2009; BonillaBedoya et al., 2018). New roads have facilitated colonization and subsequent deforestation by small-scale migrant farmers engaged in agriculture and cattle ranching (Wunder, 2003; Sierra, 2004). Indigenous peoples also migrated into the Diversity and Life Zone (DLZ) for cash-crop agriculture by indigenous peoples (Sierra, 2004; Lu et al., 2012; Davis et al., 2016). 


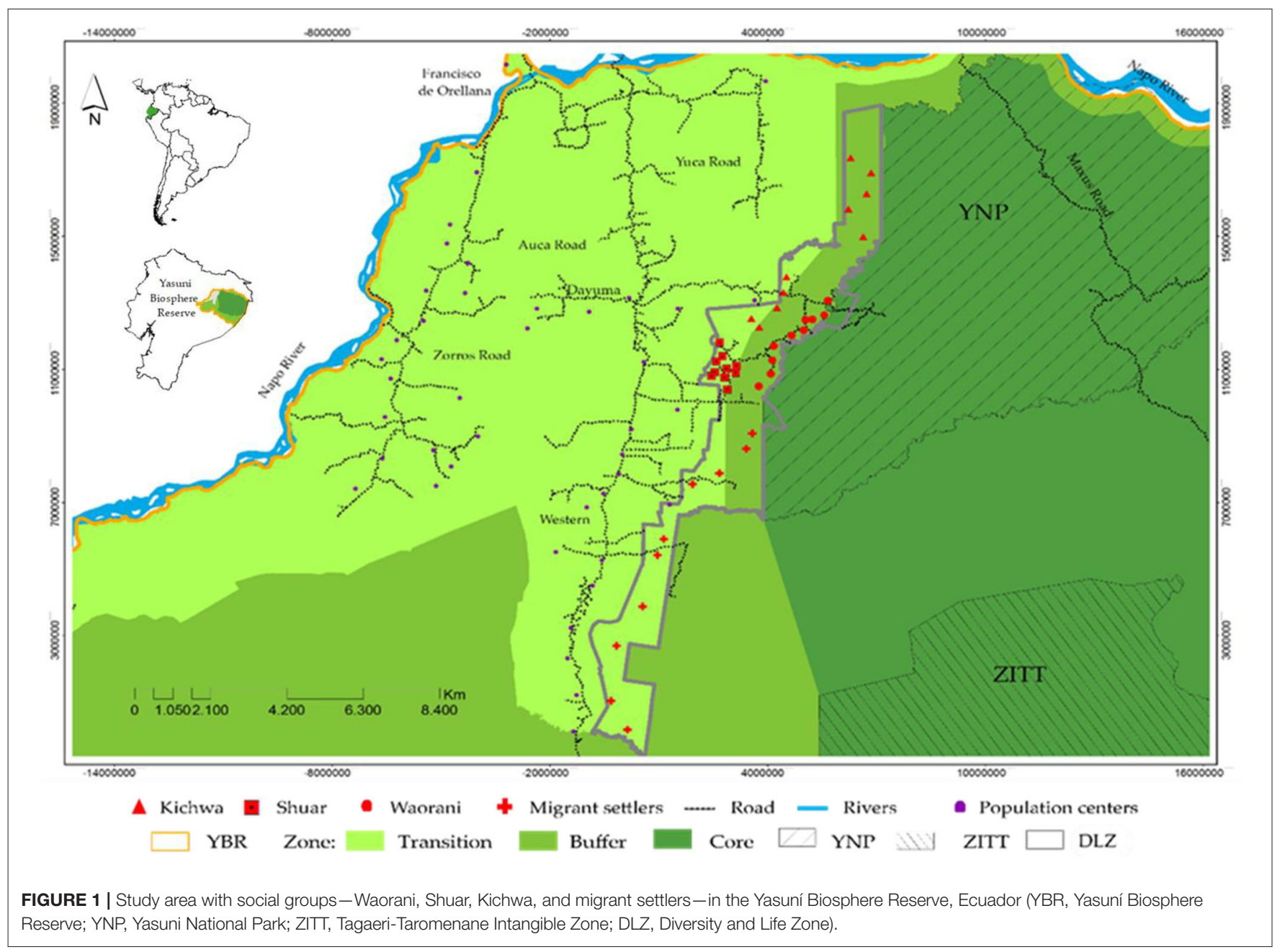

\section{Sample Design and Data Collection}

The data come from a household survey conducted between August and November 2019 in the DLZ. A template of the Poverty and Environment Network (PEN) questionnaire (Cavendish, 2003) was adopted to obtain information on the demographic characteristics of the households, the population structure by social group, and their distributions by sex and age. The following indices were calculated: (1) proportions of young population ( $<14$ years, $\left.P_{\text {youngpop }}\right)$; (2) adult population (between 15 and 64 years, $P_{\text {adults }}$ ); (3) ratio of children/women, defined as: the number of children under 5 years of age for every woman of reproductive age $(R)$; (4) masculinity rate, consisting of the ratio of males for every 100 females in a given population, which is the first indicator to analyze the population's distribution by sex $(M R)$; (5) the youth dependency index-the ratio between those $(<15$ years) who are potentially dependent and those of a potentially active age (between 15 and 64 years, $I_{d y}^{t}$ ); (6) the working age population structure index - the ratio between those aged 40-64 years and those aged 15-39 years $\left(\boldsymbol{I}_{r}\right)$; and (7) the working age population replacement index- the ratio between those aged 60-64 years and those aged $15-19$ years $\left(I_{r}^{t}\right)$; (Hinde,
2001; Rowland, 2004; Holdsworth et al., 2013; Wilson, 2016). Moreover, we determined the time needed to travel to: (a) the road and river, (b) traditional production systems for indigenous people, and (c) production systems for migrant settlers.

$$
\begin{aligned}
P_{\text {young pop. }} & =\frac{P_{0-14}}{P} \times 100 \\
P_{\text {adults }} & =\frac{P_{15-64}}{P} \times 100 \\
R & =\frac{P_{0-4}}{P_{w .15-49}} \text { children per woman } \\
M R & =\frac{\text { male } P}{P} \times 100 \\
I_{d y}^{t} & =\frac{P_{0-14}^{t}}{P_{15-64}^{t}} \times 100 \\
I_{r} & =\frac{P_{40-64}^{t}}{P_{15-39}^{t}} \times 100 \\
I_{r}^{t} & =\frac{P_{60-64}^{t}}{P_{15-19}^{t}} \times 100
\end{aligned}
$$


The cluster sampling technique was used with a two-stage approach. During the first stage, two to five communities were selected per social groups, based on criteria of ethnicity and ownership of traditional production systems. To this end, 14 communities were identified (Table 1). The variation in conditions between communities ensured a fair representation of the communities' diversity, which influences the robustness of the study (Cavendish, 2003).

During the second stage, with the support of a key informant per social group, 10 households per social group were randomly selected for a total of 40 households (10 households per social group) for the interviews. The survey was translated from English to Spanish, Kichwa, Shuar, and Wao-terëro. The 40 households (10 households per social group) housed between 3 and 13 members per household (Table 1). The survey was administered to the husband and wife of each household. Although the sample is not strictly called a probability sampling of communities and households, the 14 communities and 40 households provided a good representation of diverse ethnic or social groupings, geographies, and livelihood diversity, considering the complexity of conducting interviews in indigenous communities (Vasco et al., 2018). The process of obtaining free and informed consent was carried out with the support of indigenous leaders and settlers, through whom all approaches to households were made. Surveys were conducted according to the principles of ethical research (Vanclay et al., 2013) where the objectives, methodology, and timetable of the study were a priori explained to members of each community.

\section{Assessment of Agricultural Sustainability}

The program SAFA version 3.0 (SAFA, 2012), developed in 2012 by the FAO, was used to obtain a set of useful indicators that highlighted problems and identified solutions regarding the sustainability evaluation of the production systems, used in this case at the household level. The surveys consisted of questions based on the SAFA indicators (Food Agriculture Organization, 2014) related to agricultural systems and livelihoods. The SAFA has hierarchical levels: dimensions, themes, sub-themes, and indicators (Food Agriculture Organization, 2013). The dimensions include good governance (GG), environmental integrity (EI), economic resilience (ER), and social well-being (WB). One dimension is the pillar of sustainability, which is the highest and most general level in the SAFA structure (Food Agriculture Organization, 2014).

The SAFA usually consists of 21 themes, 58 sub-themes and 116 indicators (Food Agriculture Organization, 2013, 2014). In this research, however, the theme product quality and information (with its 3 sub-themes and 7 indicators) was not considered since none of the products produced and sold was labeled or had any traceability standards. Therefore, to assess the four dimensions of sustainability, the 20 SAFA sustainability themes, 55 sub-themes and 109 indicators (Table 2) were targeted. They were measured on a scale of 1-5 (Food Agriculture Organization, 2013) with the following sustainability levels: insufficient (red, <1.0), moderate (orange, 1.1-2), fair (yellow, 2.1-3), superior (light green, 3.1-4) and best (dark green,
>4.1) sustainability practices (Food Agriculture Organization, 2014).

The development of the SAFA included four stages: (1) mapping: description of the system to be evaluated; (2) contextualization: review of sub-themes and dynamic contexts; (3) indicators: selection of indicators and individual assessment; and (4) reporting of the information obtained at each stage, and presented in a sustainability polygon, using the SAFA version 3.0 and Excel version 2110 programs (Food Agriculture Organization, 2014). The SAFA program lists the metric tools and standards for data collection, which determine the level of data quality by attributing a variable score from 1 to 3 , where 1 corresponds to low-quality data; 2 to moderate quality data; and 3 to high-quality data (Food Agriculture Organization, 2013). The survey had a duration of 60-85 min per household.

For the definition of the evaluated topics (Annex 1 in the Supplementary Material), three field visits were made to the study area between the months of May and June 2019. The direct observation technique was used because it helped data collection and information, allowed for a more detailed analysis of the facts and realities that made up each case within the study (Campos and Martínez, 2012) and was the best method for an in-situ evaluation (Sutton and Austin, 2015).

\section{Statistical Method for Identifying Interactions Within the Dimensions of Sustainability}

An analysis of variance (ANOVA) was used to compare the traditional production systems among the four social groups. A heteroscedastic model was fitted in the case of heterogeneous variances between social groupings. When normality was not met, we utilized the non-parametric Kruskal-Wallis test (Kruskal and Wallis, 1952). For significant differences at 5\%, a Fisher's multiple comparison test was performed. For nominal variables $(0,1)$, Chi-square distribution tests were used.

A linear discriminant analysis was performed with the variables (sustainability issues) and social groupings with the aim of adjusting discriminant axes-a linear combination of the original variables-to maximize the differences between populations. The results were visualized in a biplot (variables and social groupings) in which the projection vector of the variables on the axes allows one to identify the relative contribution of the variables to the separation of the populations. Finally, synergies and trade-offs were evaluated using the non-parametric Spearman's correlation test (Spearman, 1904). Positive correlation coefficients $(0<\mathrm{r} s \leq+1)$ represent synergies, while negative correlation coefficients $(0>\mathrm{r} \mathrm{s} \geq-1)$ represent trade-offs. Analyses were performed with IBM SPSS Statistics version 21 (SPSS, 2012) and the statistical program Infostat (Di Rienzo et al., 2011).

\section{RESULTS}

This section details the sociodemographic characteristics and sustainability scores for traditional production systems; certain 
TABLE 1 | Communities in the study sample, with social groups - Waorani, Shuar, Kichwa, and migrant settlers -in the Yasuní Biosphere Reserve, Ecuador.

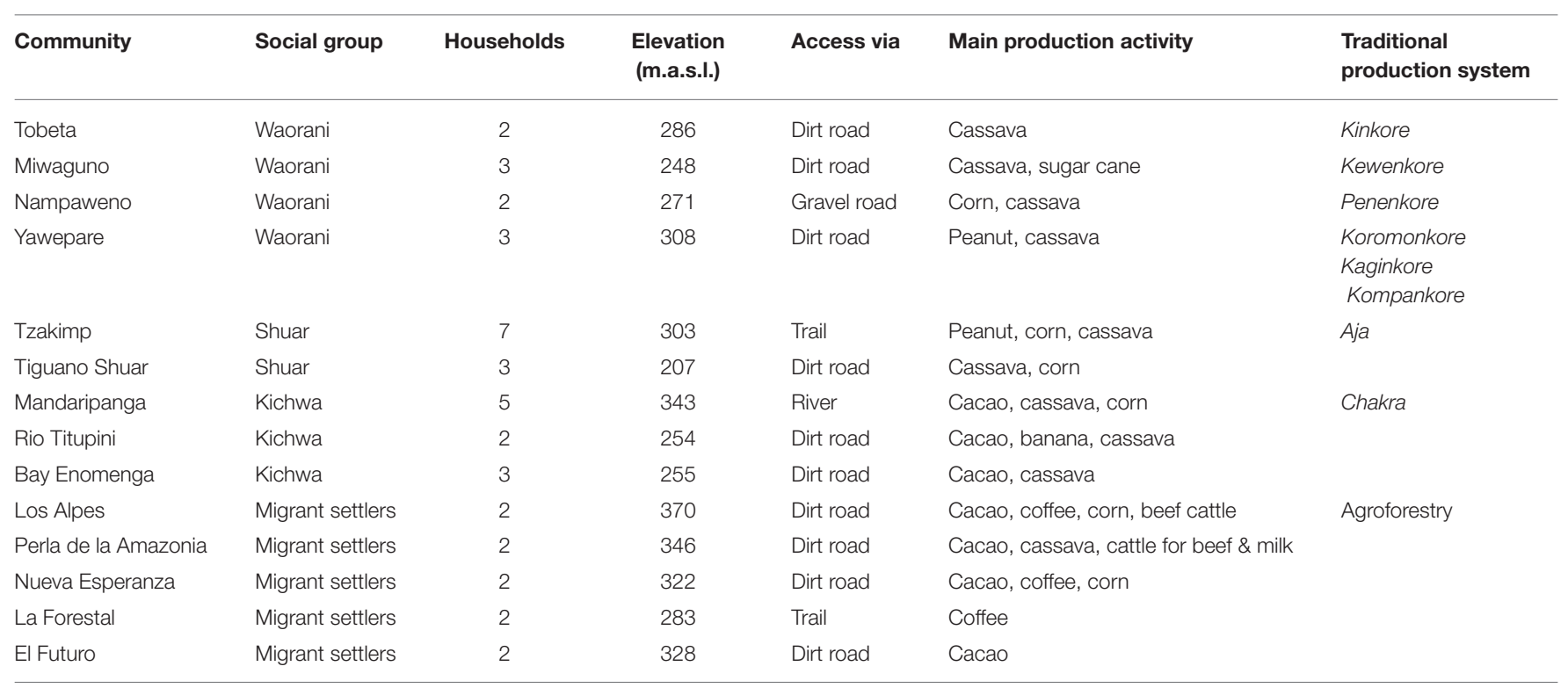

TABLE 2 | Structure of the Sustainability Assessment of Food and Agriculture (SAFA).

\begin{tabular}{lccc}
\hline Dimension & Themes & Sub-themes & Indicators \\
\hline Good governance & 5 & 14 & 19 \\
Environmental integrity & 6 & 14 & 52 \\
Economic resilience & 4 & 11 & 19 \\
Social well-being & 6 & 16 & 19 \\
\hline Total & 20 & 55 & 109 \\
\hline
\end{tabular}

Source: Food and Agriculture Organization (2015).

significant differences are evidenced in demographic terms and a narrowing between the sustainability dynamics evaluated.

\section{Sociodemographic and Agricultural Characteristics}

The population for the entire study area was composed of men $55.7 \%$ and women $44.3 \%$ (262 total), and the average age of both men and women was 27 years old. Household composition did not significantly differ among the social groups. Among the Waorani, the number of members per household varied between 4 and 13 people, while the Kichwa household had the lowest number of individuals i.e., 3 people. In the Shuar, Kichwa, and migrant settler households, the maximum number of individuals was 9 (Table 3).

The age of male heads of household differed significantly between the Shuar groups at 29 years and the other three social groups (average of 49). In terms of education, there are no significant differences among the Shuar, Kichwa, and migrant settler heads of household. However, four of Waorani heads of household no formal education, bring the level of education significantly lower at $60 \%$ than the three other groups.
The results showed no significant to marginal differences among the four groups in terms of aid for sustainable development from national or international organizations (Table 3). The Shuar and Kichwa tended to have received more help than the Waorani and migrant settlers. Access to financial credit appeared to be limited to all the four groups with only $10 \%$ of migrant settlers having some access. Access to mobile phones did not vary among the four groups but, migrant settlers tended to have highest number of mobile phones (80\%), while the Kichwa the lowest. The distance from the household (in minutes) to the main road or to the river port significantly varied, with the longest time to reach the river port $(72 \mathrm{~min}$ ) was for the Kichwa group (specifically the Mandaripanga community). The Waorani households had the lowest times, with some only having a $2 \mathrm{~min}$ distance to reach the main road. For the Shuar and migrant settlers, the average time varied between 12 and $19 \mathrm{~min}$.

Demographic indices, such as percentages of young and adult in the populations, were not significantly different among the four social groups (Table 4). Nonetheless, the Shuar appeared to have the lowest young population, comprised of $18.9 \%$ men and $8.1 \%$ women, and the highest adult population, made up of $37.8 \%$ men and $35.2 \%$ women. As expected, this led to having the lowest rate of youth dependency and the highest percent of working-age people, meaning that their replacement rate for future work was the lowest. The other three groups tended to have similar trends with more youth and less working-age population.

The average agricultural land size per household varied from 1.75 ha for the Shuar group to 3.9 ha for the migrant stellers, and these results were significant (Table 5). The Shuar had the largest forested area followed by Waorani and Kichwa and finally the migrant settlers, which was significantly the lowest in surface area. While the number of staple crops remained similar for the four social groups, the Kichwa and migrant settlers tended to cultivate at least one more cash crop than the Waorani and Shuar (Table 5). While the Kichwa tended to be closer to their 
TABLE 3 | Sociodemographic characteristics of the four social groups evaluated in the Yasuní Biosphere Reserve, Amazon region of Ecuador.

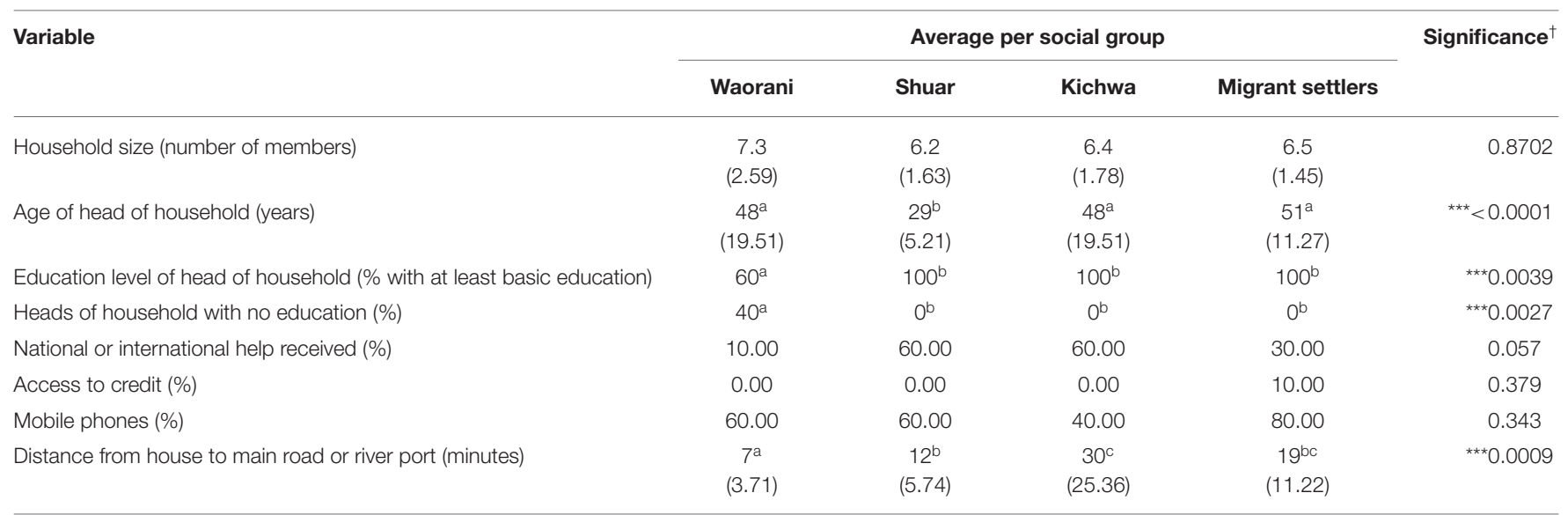

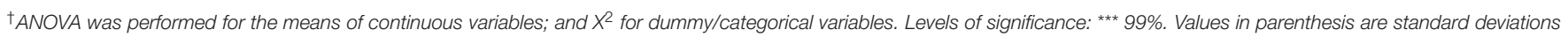
of the means. Letters in superscript denote significant differences based on the ANOVA and $X^{2}$-tests.

TABLE 4 | Demographic indices according to social grouping (Waorani, Shuar, Kichwa, and migrant settlers) in the Yasuní Biosphere Reserve of the Amazon region of Ecuador.

\begin{tabular}{|c|c|c|c|c|c|}
\hline Variable & \multicolumn{5}{|c|}{ Average per social group } \\
\hline Adult population: 15-64 (\%) & 56.9 & 73.0 & 60.9 & 67.8 & 0.2043 \\
\hline Ratio of children per woman & 1.1 & 0.5 & 0.2 & 1.2 & $0.0500^{\star \star}$ \\
\hline Percent of men (\%) & 56.9 & 56.8 & 50.0 & 59.3 & 0.7469 \\
\hline Replacement rate of the working-age population (\%) & 83.3 & 16.7 & 27.3 & 50.0 & 0.3278 \\
\hline
\end{tabular}

$x^{2}$ for dummy/categorical variables. Significance levels: ** $95 \%$.

agricultural system, the results were not significant due to high variation in distances for both migrant settlers and Waorani. The distance to the forest, however, significant differed among groups with the Shuar being closer to the firested areas than the other groups.

\section{Sustainability Dimensions Assessment}

The four dimensions of sustainability were analyzed using the 55 from the 58 SAFA sub-themes for the four traditional production systems. We found that 20 of the 55 (36.4\%) of the evaluated subthemes had significant differences among the four social groups (Table 6) and the sustainability polygons displayed in Figure 2.

\section{Good Governance Dimension}

The mean performance scores for the social groups were as follows: Waorani (1.92), followed by the Shuar group (2.59), the Migrant settler group (2.65), and the highest mean for the Kichwa (2.71). Of the 14 sub-themes evaluated, six showed significant differences among the four social groups. Mission statement, and legitimacy resource appropriation subthemes were always significantly lower for the Waorani group than the others. It was similar for the subthemes, stakeholder dialogue, and sustainability management plan. However, the Migrant settler group was not significantly different from the Waorani. In terms of overall scores, full cost accounting was the lowest followed by sustainability management plan, grievance procedures, and conflict resolutions.

\section{Environmental Integrity Dimension}

The average performance scores for the social groups were as follows: Kichwa (2.69), migrant settlers (2.78), Waorani (2.95), and the highest mean for the Shuar (3.33). Of the 14 sub-themes evaluated, four showed significant differences among the four social groups. Greenhouse gases were similar for the Waorani and Shuar but different for the Kichwa and migrant settlers, while ecosystem diversity, animal health and freedom from stress were significantly lower for the Waorani group than the others. In terms of overall scores, freedom from stress was the lowest, followed by animal health, air quality, and material use.

\section{Economic Resilience Dimension}

The mean performance scores for the social groups were as follows: the lowest mean for the Waorani (1.40), Kichwa (1.48), migrant settlers (2.48), and Shuar (2.50). Of the 11 sub-themes 
TABLE 5 | Agricultural variables (mean and standard deviation in parentheses) of the traditional productive systems of the Waorani, Shuar, Kichwa indigenous peoples and migrant settlers in the Yasuní Biosphere Reserve, Amazon Region of Ecuador.

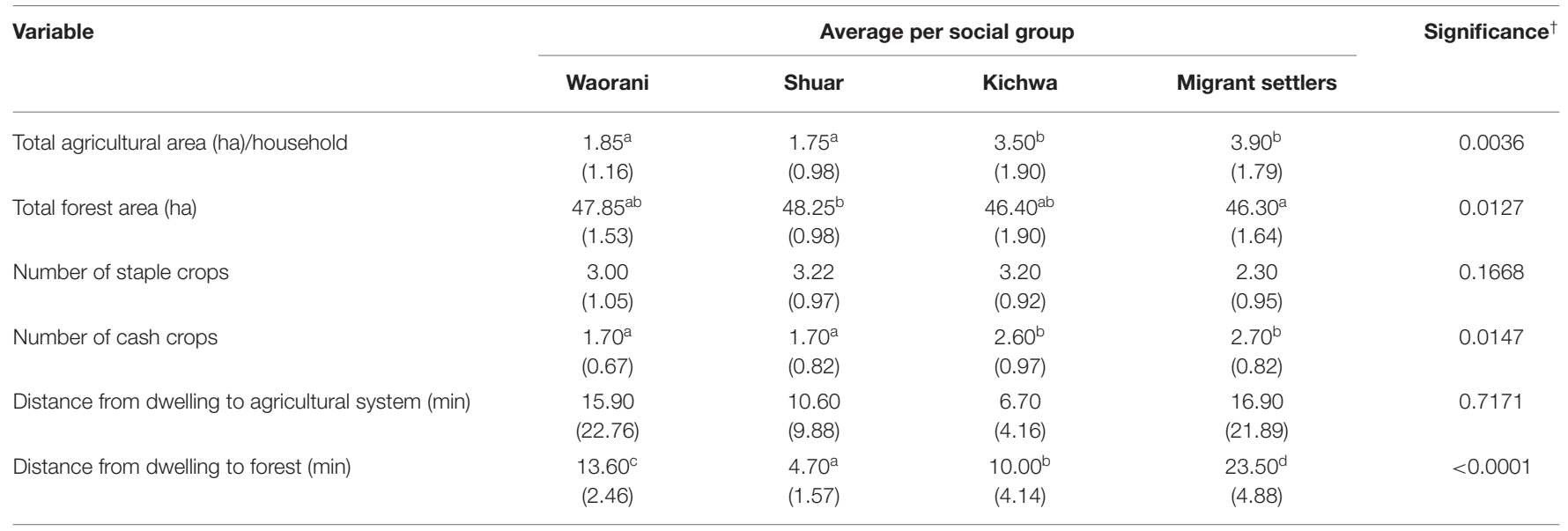

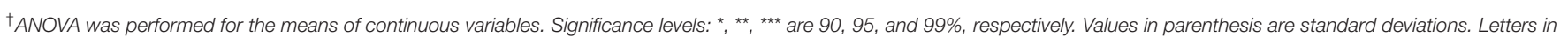
superscript denote significant differences based on the post-hoc multiple range tests.

evaluated, six showed significant differences among the four social groups. The internal investment, community investment, long-ranging investment, and profitability were significantly lower for the Waorani and Kichwa groups while, the stability of market for the migrant settlers was slightly higher for the others and local procurement for the Kichwa was slightly lower than the other groups. In terms of overall scores, the stability of market was the lowest, followed by the stability of supply, liquidity, and risk management.

\section{Social Welfare Dimension}

The average performance scores for the social groups were as follows: the lowest average for the Shuar (2.41), Kichwa (2.44), Waorani (2.54), and the highest average for the Migrant settlers (2.47). Of the 16 sub-themes evaluated, six showed significant differences among the four social groups: the quality of life for the Waorani group; the indigenous knowledge and food sovereignty for the Shuar; the gender equality, support for vulnerable people and public health for the Kichwa were significantly lower than the others. The public health was significantly higher in Kichwa than the others; the indigenous knowledge is the main difference between the Shuar and Kichwa groups; the food sovereignty in the Kichwa group is significantly different from the others. In terms of overall scores, responsible buyers were the lowest, followed by the rights of suppliers, child labor, forced labor, freedom of association, and rights to bargaining.

\section{Interactions Within Sustainability Dimensions and Themes}

Before evaluating the sustainability interactions within the four dimensions and 20 themes according to SAFA, it was necessary to quantify their results (Table 7). The results showed that the sustainability indices had a performance level of "moderate." In general, the traditional aja system (2.84) had the best score, followed by the migrant settlers' agroforestry system (2.65), considering that the themes with lower performance scores are: fair trading practices, labor rights, animal welfare and holistic management. They were followed by the Kichwa's chakra system, influenced by its lowest scoring themes: fair trading practices, investment, vulnerability, and labor rights. In last place was the Waorani's kewenkore whose lowest scores were in the themes: fair trading practices, investment, animal welfare, and holistic management.

From the scores of the four dimensions and the 20 sustainability themes (Table 7), interactions within the sustainability themes were analyzed using a Spearman's correlation test. In general terms, trade-offs and synergies were found (50\%) (Table 8). There were trade-offs between good governance and environment integrity (15\%), followed by social issues (11\%), and synergies (25\%) with respect to economic resilience. In addition, significant synergies were observed within environmental integrity with economic and social issues, and trade-offs between economic resilience and social well-being.

\section{Multivariate Discriminant Analysis by Social Groups}

Similarities and antagonisms in terms of sustainability among the social groups were identified with a multivariate discriminant analysis, using the averages of the 116 sustainability indicators of the four dimensions of the SAFA methodology (Figure 3). The results showed that in the horizontal component $(60 \%$ of the variation between groups), the social groups were ordered by placing the traditional systems of the Shuar population on the extreme right together with those of migrant settlers because they showed similarities. On the far left were the Waorani and Kichwa cases, which differed in certain aspects to the two aforementioned groups. These differences between the social groups were mainly explained by a contrast or negative correlation between the investment, atmosphere, and materials themes vs. the participation. In this sense, the Shuar and migrant settler populations were characterized by high levels of investment, atmosphere, and materials (although also in biodiversity, animal 
TABLE 6 | Sub-themes evaluated in the four traditional production systems evaluated by social groups in the Yasuní Biosphere Reserve's Diversity and Life Zone, Amazon region of Ecuador.

\begin{tabular}{|c|c|c|c|c|c|c|}
\hline Dimensions & Sub-theme & $\begin{array}{l}\text { Waorani } \\
\text { average } \\
\text { (SD) }\end{array}$ & $\begin{array}{l}\text { Shuar } \\
\text { average } \\
\text { (SD) }\end{array}$ & $\begin{array}{c}\text { Kichwa } \\
\text { average } \\
\text { (SD) }\end{array}$ & $\begin{array}{l}\text { Migrant settler } \\
\text { average } \\
\text { (SD) }\end{array}$ & Significance $^{\dagger}$ \\
\hline \multirow{21}{*}{ 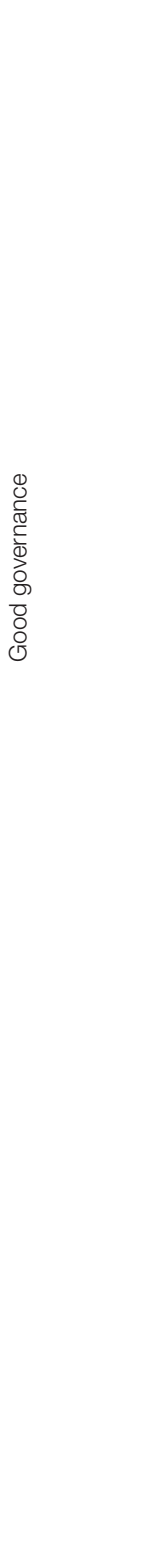 } & Mission statement & $\begin{array}{l}2.68^{\mathrm{a}} \\
(0.59)\end{array}$ & $\begin{array}{l}3.37^{b} \\
(0.59)\end{array}$ & $\begin{array}{l}3.36^{b} \\
(0.74)\end{array}$ & $\begin{array}{l}3.38^{b} \\
(0.46)\end{array}$ & 0.031 \\
\hline & Due diligence & $\begin{array}{c}2.50 \\
(0.63)\end{array}$ & $\begin{array}{c}3.26 \\
(0.66)\end{array}$ & $\begin{array}{c}3.09 \\
(1.07)\end{array}$ & $\begin{array}{c}3.17 \\
(1.06)\end{array}$ & 0.224 \\
\hline & Holistic audits & $\begin{array}{c}2.49 \\
(0.72)\end{array}$ & $\begin{array}{c}2,99 \\
(0.96)\end{array}$ & $\begin{array}{c}2.38 \\
(1.10)\end{array}$ & $\begin{array}{c}2.81 \\
(1.59)\end{array}$ & 0.611 \\
\hline & Responsibility & $\begin{array}{c}2.23 \\
(0.74)\end{array}$ & $\begin{array}{c}2.41 \\
(0.65)\end{array}$ & $\begin{array}{c}2.55 \\
(0.50)\end{array}$ & $\begin{array}{c}2.66 \\
(0.91)\end{array}$ & 0.574 \\
\hline & Transparency & $\begin{array}{c}2.43 \\
(0.57)\end{array}$ & $\begin{array}{c}2.56 \\
(0.63)\end{array}$ & $\begin{array}{l}2.47 \\
(0.93)\end{array}$ & $\begin{array}{c}3.01 \\
(0.79)\end{array}$ & 0.290 \\
\hline & Stakeholder dialogue & $\begin{array}{l}2.04^{a} \\
(0.79)\end{array}$ & $\begin{array}{l}2.85^{b} \\
(1.20)\end{array}$ & $\begin{array}{l}3.30^{b} \\
(0.51)\end{array}$ & $\begin{array}{l}2.30^{a} \\
(0.85)\end{array}$ & 0.012 \\
\hline & Grievance procedures & $\begin{array}{c}1.83 \\
(0.45)\end{array}$ & $\begin{array}{c}2.12 \\
(0.98)\end{array}$ & $\begin{array}{c}2.78 \\
(1.16)\end{array}$ & $\begin{array}{c}2.12 \\
(0.43)\end{array}$ & 0.089 \\
\hline & Conflict resolution & $\begin{array}{c}2.04 \\
(0.65)\end{array}$ & $\begin{array}{c}2.00 \\
(0.79)\end{array}$ & $\begin{array}{c}2.57 \\
(1.05)\end{array}$ & $\begin{array}{c}2.1 \\
(0.76)\end{array}$ & 0.397 \\
\hline & Legitimacy & $\begin{array}{l}1.24^{\mathrm{a}} \\
(0.47)\end{array}$ & $\begin{array}{l}2.68^{b} \\
(1.40)\end{array}$ & $\begin{array}{l}3.01^{b} \\
(0.95)\end{array}$ & $\begin{array}{l}3.26^{b} \\
(0.78)\end{array}$ & $<0.001$ \\
\hline & Remedy restoration and prevention & $\begin{array}{c}1.92 \\
(0.73)\end{array}$ & $\begin{array}{c}2.95 \\
(0.67)\end{array}$ & $\begin{array}{l}2.87 \\
(1.1)\end{array}$ & $\begin{array}{c}2.78 \\
(1.14)\end{array}$ & 0.066 \\
\hline & Civic responsibility & $\begin{array}{l}1.24^{a} \\
(0.66)\end{array}$ & $\begin{array}{l}2.57^{b} \\
(0.85)\end{array}$ & $\begin{array}{l}2.74^{b} \\
(0.89)\end{array}$ & $\begin{array}{l}3.00^{b} \\
(1.18)\end{array}$ & 0.001 \\
\hline & Resource appropriation & $\begin{array}{l}1.73^{\mathrm{a}} \\
(0.34)\end{array}$ & $\begin{array}{l}2.89^{b} \\
(0.95)\end{array}$ & $\begin{array}{l}2.98^{b} \\
(1.30)\end{array}$ & $\begin{array}{l}2.87^{\mathrm{b}} \\
(0.98)\end{array}$ & 0.017 \\
\hline & Sustainability management plan & $\begin{array}{l}1.44^{\mathrm{a}} \\
(0.68)\end{array}$ & $\begin{array}{l}2.52^{b} \\
(0.97)\end{array}$ & $\begin{array}{l}2.33^{b} \\
(1.02)\end{array}$ & $\begin{array}{l}2.03^{b} \\
(0.73)\end{array}$ & 0043 \\
\hline & Full cost accounting & $\begin{array}{c}1,03 \\
(0.37)\end{array}$ & $\begin{array}{c}0.98 \\
(0.78)\end{array}$ & $\begin{array}{c}1.50 \\
(0.87)\end{array}$ & $\begin{array}{c}1.50 \\
(1.00)\end{array}$ & 0.272 \\
\hline & Mean & $\begin{array}{l}1.92^{\mathrm{a}} \\
(0.53)\end{array}$ & $\begin{array}{l}2.59^{b} \\
(0.60)\end{array}$ & $\begin{array}{l}2.71^{b} \\
(0.47)\end{array}$ & $\begin{array}{l}2.65^{b} \\
(0.54)\end{array}$ & 0.007 \\
\hline & Greenhouse gases & $\begin{array}{l}3.40^{\mathrm{a}} \\
(0.77)\end{array}$ & $\begin{array}{l}2.96^{a} \\
(0.78)\end{array}$ & $\begin{array}{l}2.38^{b} \\
(0.63)\end{array}$ & $\begin{array}{l}2.40^{\mathrm{b}} \\
(1.17)\end{array}$ & 0.034 \\
\hline & Air quality & $\begin{array}{c}2.96 \\
(0.61)\end{array}$ & $\begin{array}{c}305 \\
(0.96)\end{array}$ & $\begin{array}{c}2.11 \\
(0.93)\end{array}$ & $\begin{array}{c}2.47 \\
(1.16)\end{array}$ & 0.106 \\
\hline & Water withdrawal & $\begin{array}{c}3.63 \\
(0.83)\end{array}$ & $\begin{array}{c}3.95 \\
(0.41)\end{array}$ & $\begin{array}{c}3.46 \\
(0.42)\end{array}$ & $\begin{array}{c}3.48 \\
(0.72)\end{array}$ & 0.279 \\
\hline & Water quality & $\begin{array}{c}3.90 \\
(0.70)\end{array}$ & $\begin{array}{c}3.94 \\
(0.45)\end{array}$ & $\begin{array}{c}3.21 \\
(1.10)\end{array}$ & $\begin{array}{c}3.30 \\
(0.84)\end{array}$ & 0.398 \\
\hline & Soil quality & $\begin{array}{c}347 \\
(0.64)\end{array}$ & $\begin{array}{c}3.54 \\
(0.67)\end{array}$ & $\begin{array}{c}3.34 \\
(1.06)\end{array}$ & $\begin{array}{c}3.04 \\
(0.63)\end{array}$ & 0.286 \\
\hline & Land degradation & $\begin{array}{c}3.17 \\
(0.59)\end{array}$ & $\begin{array}{c}3.46 \\
(0.58)\end{array}$ & $\begin{array}{c}2.77 \\
(1.23)\end{array}$ & $\begin{array}{c}3.46 \\
(0.53)\end{array}$ & 0.207 \\
\hline \multirow{5}{*}{ 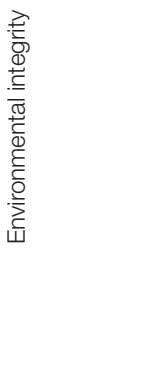 } & Ecosystem diversity & $\begin{array}{l}3.04^{a} \\
(0.77)\end{array}$ & $\begin{array}{l}3.98^{b} \\
(0.46)\end{array}$ & $\begin{array}{l}3.79^{b} \\
(0.12)\end{array}$ & $\begin{array}{l}3.26^{a} \\
(0.57)\end{array}$ & 0.014 \\
\hline & Species diversity & $\begin{array}{c}3.32 \\
(1.07)\end{array}$ & $\begin{array}{c}3.49 \\
(0.76)\end{array}$ & $\begin{array}{c}3.45 \\
(0.60)\end{array}$ & $\begin{array}{c}3.14 \\
(0.87)\end{array}$ & 0.791 \\
\hline & Genetic diversity & $\begin{array}{c}3.05 \\
(0.42)\end{array}$ & $\begin{array}{c}3.67 \\
(0.71)\end{array}$ & $\begin{array}{c}3.15 \\
(1.89)\end{array}$ & $\begin{array}{c}2.71 \\
(0.88)\end{array}$ & 0.303 \\
\hline & Material use & $\begin{array}{c}2.73 \\
(0.99)\end{array}$ & $\begin{array}{c}2.96 \\
(0.56)\end{array}$ & $\begin{array}{l}2.45 \\
(0.95)\end{array}$ & $\begin{array}{l}2.67 \\
(0.98)\end{array}$ & 0.647 \\
\hline & Energy use & $\begin{array}{c}3.26 \\
(0.61)\end{array}$ & $\begin{array}{c}2.93 \\
(0.84)\end{array}$ & $\begin{array}{c}2.38 \\
(1.03)\end{array}$ & $\begin{array}{c}2.98 \\
(0.65)\end{array}$ & 0.114 \\
\hline
\end{tabular}


TABLE 6 | Continued

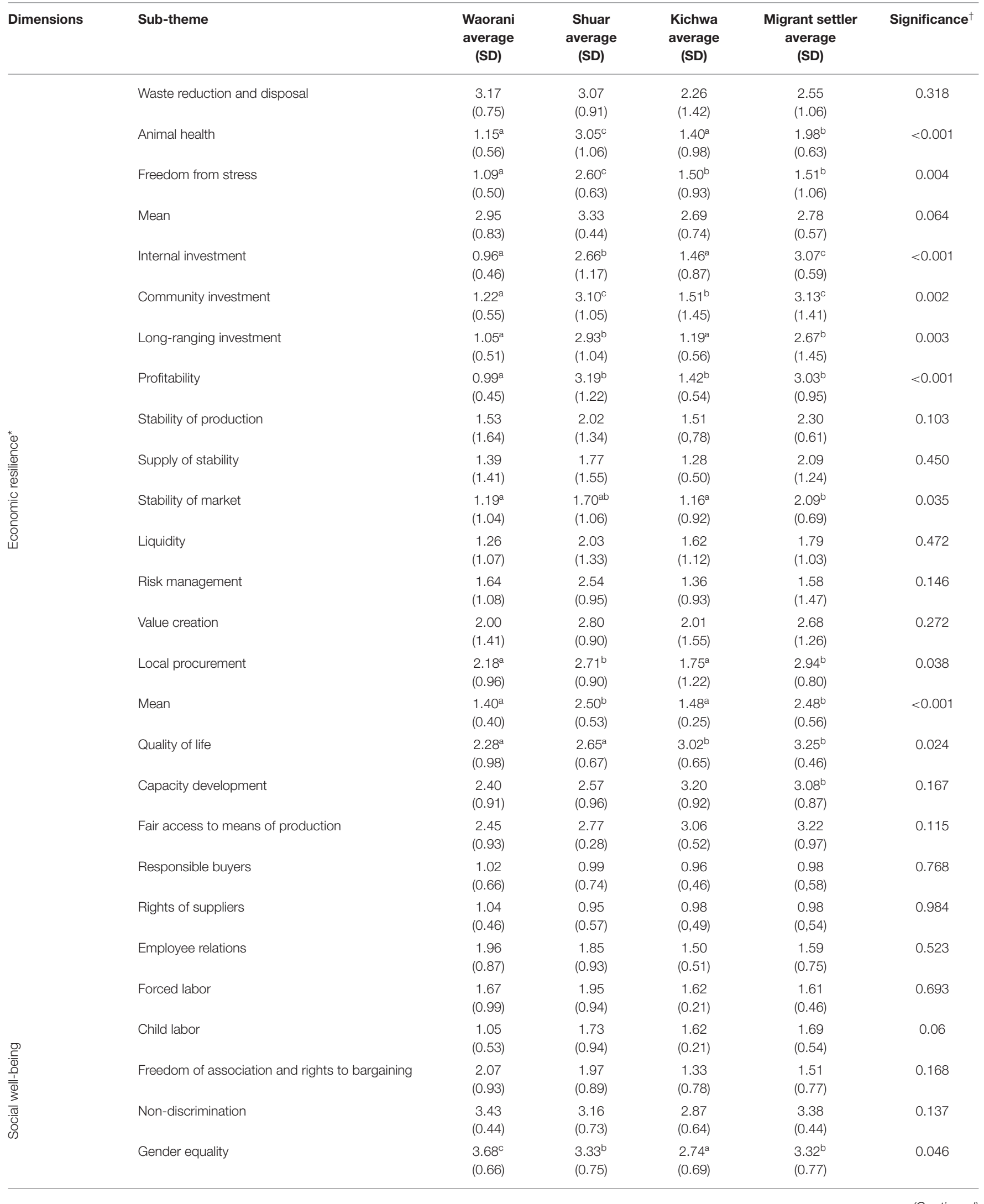


TABLE 6 | Continued

\begin{tabular}{|c|c|c|c|c|c|c|}
\hline Dimensions & Sub-theme & $\begin{array}{l}\text { Waorani } \\
\text { average } \\
\text { (SD) }\end{array}$ & $\begin{array}{l}\text { Shuar } \\
\text { average } \\
\text { (SD) }\end{array}$ & $\begin{array}{l}\text { Kichwa } \\
\text { average } \\
\text { (SD) }\end{array}$ & $\begin{array}{l}\text { Migrant settler } \\
\text { average } \\
\text { (SD) }\end{array}$ & Significance $^{\dagger}$ \\
\hline & Support for vulnerable people & $\begin{array}{l}3.82^{\mathrm{c}} \\
(0.79)\end{array}$ & $\begin{array}{l}3.05^{a} \\
(0.35)\end{array}$ & $\begin{array}{l}2.90^{a} \\
(0.66)\end{array}$ & $\begin{array}{l}3.45^{b} \\
(0.35)\end{array}$ & 0.004 \\
\hline & Workplace safety and health provisions & $\begin{array}{c}2.98 \\
(0.66)\end{array}$ & $\begin{array}{c}2.69 \\
(0.87)\end{array}$ & $\begin{array}{c}2.26 \\
(0.63)\end{array}$ & $\begin{array}{c}2.57 \\
(0.71)\end{array}$ & 0.183 \\
\hline & Public health & $\begin{array}{l}3.39^{c} \\
(0.79)\end{array}$ & $\begin{array}{l}2.60^{b} \\
(0.75)\end{array}$ & $\begin{array}{l}2.12^{a} \\
(0.84)\end{array}$ & $\begin{array}{l}2.45^{b} \\
(0.56)\end{array}$ & 0.004 \\
\hline & Indigenous knowledge & $\begin{array}{l}3.82^{b} \\
(0.47)\end{array}$ & $\begin{array}{l}3.15^{a} \\
(0.82)\end{array}$ & $\begin{array}{l}4.40^{\mathrm{b}} \\
(0.21)\end{array}$ & $\begin{array}{l}3.26^{a} \\
(0.91)\end{array}$ & 0.001 \\
\hline & Food sovereignty & $\begin{array}{l}3.65^{b} \\
(0.75)\end{array}$ & $\begin{array}{l}3.07^{a} \\
(0.66)\end{array}$ & $\begin{array}{l}4.45^{b} \\
(0.16)\end{array}$ & $\begin{array}{l}3.19^{a} \\
(0.81)\end{array}$ & $<0.001$ \\
\hline & Mean & $\begin{array}{c}2.54 \\
(1.02)\end{array}$ & $\begin{array}{c}2.41 \\
(0.75)\end{array}$ & $\begin{array}{c}2.44 \\
(1.08)\end{array}$ & $\begin{array}{c}2.47 \\
(0.98)\end{array}$ & 0.979 \\
\hline
\end{tabular}

${ }^{\dagger}$ ANOVA or ${ }^{*} K r$ ruskal-Wallis as appropriate. Different letters indicate significant differences between social groups at $5 \%$.

welfare, and vulnerability) and low levels of participation. The opposite occurred with the Kichwa and Waorani populations. The vertical component (30\% of the variation between groups) separated the Waorani indigenous populations from the Kichwa. This indicated that the Kichwa population was characterized by high values of good governance: participation, holistic audits, and social well-being: decent livelihood (we can add equity and cultural diversity), in contrast to the Waorani population, which was related to high values for labor rights, human, and equity.

\section{DISCUSSION}

\section{Assessment of Sustainability Dimensions}

When comparing the four dimensions of sustainability between the traditional production systems (Waorani, Shuar, Kichwa, and migrant settlers), we found that the sustainability profiles by sub-themes are more statistically different in the dimensions of good governance and social well-being in contrast to the dimensions of environmental integrity and economic resilience (Table 7). This is consistent with the dynamics of management in traditional production systems among the Waorani (ZuritaBenavides, 2017), Shuar (Karsten et al., 2000), Kichwa (CoqHuelva et al., 2017; Luzuriaga-Quichimbo et al., 2019), and migrant settlers (Sellers et al., 2017; Heredia-R et al., 2020a,b,c; Viteri-Salazar and Toledo, 2020). It is related to different cultural and migratory dynamics (Barbieri et al., 2009), such as, mining and land redistribution in favor of settlers. Some Shuar populations had to migrate to the province of Orellana and other provinces of the Ecuadorian Amazon (Holt et al., 2004), when the migrant settlers arrived mainly from the highlands and coast (Barbieri and Carr, 2005; Wasserstrom, 2010; Viteri-Salazar and Toledo, 2020).

None of the traditional production systems works uniformly for all themes (Table 3) and sub-themes (Figure 2) of sustainability. This may be related to social or environmental conflicts (Scheidel et al., 2020) and market access, as has been demonstrated in other indigenous populations, for instance the Baka of Cameroon (Africa), the Punan Tubu of Indonesia
(Asia), and the Tsimane' of Bolivia (South America), where three relatively isolated societies, largely dependent on traditional subsistence systems (Joiris, 2003; Levang et al., 2007; Leclerc, 2012; Reyes-García et al., 2014; Díaz-Reviriego et al., 2016), saw their diets alter when living closer to markets. This shifted their consumption habits from nutritional food (i.e., fruit, vegetables, and food of animal origin) to an increased consumption of fats and sweet products due to market integration, thus decreasing work in traditional production systems (Reyes-García et al., 2019).

The low scores of the Waorani (kinkore) traditional production systems for good governance (Table 7) are influenced by the holistic management theme and correlated with the sub-themes of sustainability management plan and full cost accounting (Figure 2 and Table 6). This contrasts with the common belief that indigenous populations are associated with a holistic management of their traditional systems (long fallows, according to Boserup, 1965), with collective responsibility, participation and, therefore, compatibility with resource conservation (Dufour, 1990; Schwartzman et al., 2000). However, several studies (Henrich, 1997; Zimmerman et al., 2001; Rudel et al., 2002; Godoy et al., 2005; Gray et al., 2008; Porro et al., 2014) indicate that indigenous peoples sometimes also engage in unsustainable practices (Food Agriculture Organization, 2005), driven by the presence of oil activity (Rivera-Parra et al., 2020), which has negative implications (Diantini et al., 2020). The Waorani stand in contrast to the Shuar's aja, which had the highest scores, thus complying with Boserup's assertion (Boserup, 1965) regarding systems with more sustainable levels of governance (Rudel et al., 2002).

In the environmental integrity dimension, the low scores obtained by the migrant settlers are related to the themes of animal welfare (driven by the sub-themes of animal health and freedom from stress) and atmosphere (driven by the sub-themes of greenhouse gases and air quality). An explanation for this finding is that pastoral systems in the EAR are associated with extensive operations (Lerner et al., 2014; MAGAP, 2014). Therefore, they require larger areas 


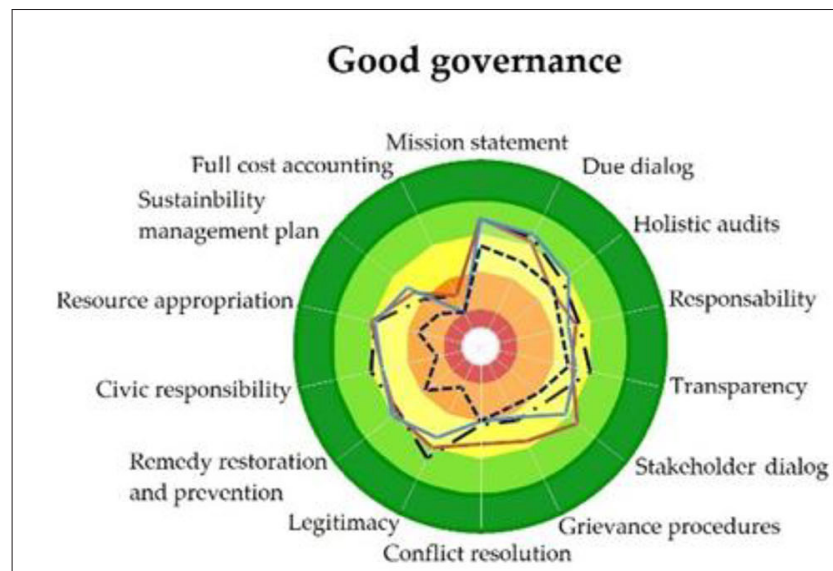

Economic Resilience

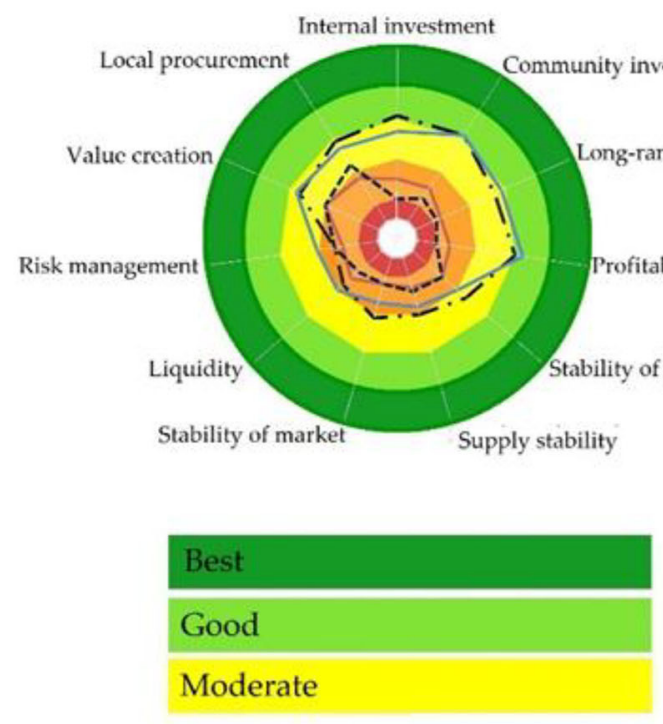

Kinkore
Waorani $\quad \begin{gathered}\text { Aja } \\ \text { Shuar }\end{gathered}$

\section{Environmental integrity}

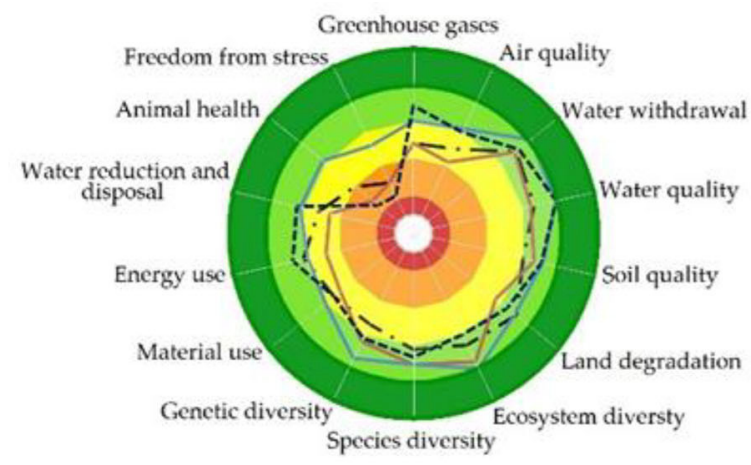

Social well-being

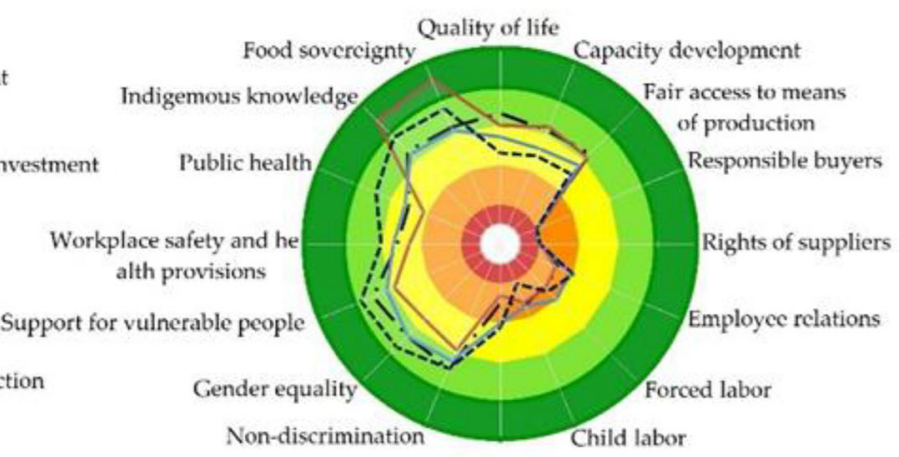

Freedom of association and rights to bargaining

\begin{tabular}{|l|}
\hline Limited \\
\hline Unacceptable \\
\hline Not relevant \\
\hline
\end{tabular}

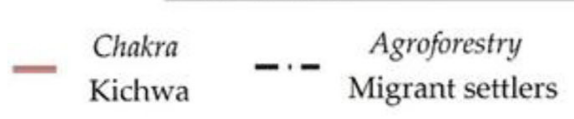

FIGURE 2 | Comparison of the dimensions of good governance, environmental integrity, economic resilience, and social well-being in the four traditional production systems in the Yasuní Biosphere Reserve, Amazon region of Ecuador.

of land. In tropical regions, livestock development is being promoted with an economically, socially, and environmentally sustainable approach (Ness et al., 2007). Cattle ranching offers an alternative source of capital that the rural poor can accumulate as a "savings account" to protect themselves against income fluctuations (Broom et al., 2013; Lemaire et al., 2014). Therefore, raising cattle in rural households is considered an alternative form of insurance, allowing them to earn income from the sale of animals in times of crisis (Hoddinott, 2006; Mogues, 2011). The welfare of ethnic minority households with livestock production tends to be higher than those without livestock production (Truong et al., 2020), and sustainability depends on the availability of resources for transformation to agrosilvopastoral systems (Lopera-Marín et al., 2020).

In relation to economic resilience, the low scores of the Waorani (kinkore) traditional production systems are related to the theme of investment and the sub-themes internal investment, community investment, long-term investment, and profitability. First, the Waorani have recently become integrated into the markets (Sierra et al., 1999; Franzen and James, 2007; Lu, 2007), driven by certain factors: accessibility, monetary income, trade of agricultural products, and wild meat, and a cultural erosion of exchange (Donders and Barriocanal, 2020). Oil exploitation in the Amazon basin is an additional factor, whereby some Waorani are economically dependent on salaried jobs in the oil industry 
TABLE 7 | Means and standard deviations of the themes of the sustainability evaluation in four production systems (Waorani, Shuar, Kichwa, and migrant settlers) in the Yasuní Biosphere Reserve, Amazon region of Ecuador.

\begin{tabular}{|c|c|c|c|c|c|c|c|c|c|c|c|}
\hline \multicolumn{2}{|c|}{ Dimension/Theme } & \multicolumn{2}{|c|}{$\begin{array}{l}\text { Waorani } \\
\text { (Kinkore) }\end{array}$} & \multicolumn{2}{|c|}{$\begin{array}{l}\text { Shuar } \\
\text { (Aja) }\end{array}$} & \multicolumn{2}{|c|}{$\begin{array}{l}\text { Kichwa } \\
\text { (Chakra) }\end{array}$} & \multicolumn{2}{|c|}{$\begin{array}{c}\text { Migrant settlers } \\
\text { (agroforestry) }\end{array}$} & \multirow[t]{2}{*}{$\begin{array}{l}\text { Overall } \\
\text { mean }\end{array}$} & \multirow[t]{2}{*}{ Significance $^{\dagger}$} \\
\hline & & Mean & SD & Mean & SD & Mean & SD & Mean & SD & & \\
\hline \multirow{5}{*}{ 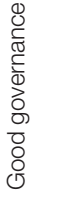 } & GG1. Corporate ethics & 2.75 & 0.93 & 3.35 & 0.18 & 3.42 & 0.50 & 3.41 & 0.28 & 3.23 & - \\
\hline & GG2. Accountability & $2.53^{a b}$ & 0.68 & $3.20^{c}$ & 0.49 & $2.06^{\mathrm{a}}$ & 0.76 & $3.00^{\mathrm{bc}}$ & 0.78 & 2.70 & ** \\
\hline & GG3. Participation & $2.05^{\mathrm{a}}$ & 0.52 & $2.97^{\mathrm{b}}$ & 0.71 & $3.41^{b}$ & 0.52 & $2.36^{\mathrm{a}}$ & 0.59 & 2.70 & 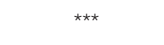 \\
\hline & GG4. Rule of law & $2.00^{a}$ & 0.74 & $3.03^{b}$ & 0.46 & $3.06^{b c}$ & 0.60 & $3.43^{c}$ & 0.19 & 2.88 & 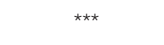 \\
\hline & GG5. Holistic management & $1.50^{\mathrm{a}}$ & 0.22 & $2.61^{b}$ & 0.40 & $2.42^{b}$ & 0.30 & $2.19^{b}$ & 0.72 & 2.18 & 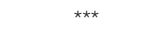 \\
\hline \multirow{6}{*}{ 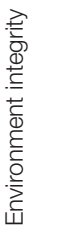 } & El1. Atmosphere & $3.42^{\mathrm{a}}$ & 0.25 & $3.19^{a}$ & 0.56 & $2.60^{b}$ & 0.27 & $2.56^{b}$ & 0.57 & 2.94 & $* \star *$ \\
\hline & El2. Water & 3.91 & 0.71 & 4.09 & 0.57 & 3.51 & 0.53 & 3.59 & 0.61 & 3.78 & - \\
\hline & El3. Land & 3.60 & 0.37 & 3.53 & 0.49 & 3.31 & 0.50 & 3.16 & 0.98 & 3.40 & - \\
\hline & El4. Biodiversity & $3.55^{\mathrm{ab}}$ & 0.69 & $4.07^{b}$ & 0.56 & $3.92^{b}$ & 0.70 & $3.31^{\mathrm{a}}$ & 0.40 & 3.71 & $\star \star$ \\
\hline & El5. Materials and energy & $3.45^{\mathrm{c}}$ & 0.14 & $3.33^{\mathrm{bc}}$ & 0.27 & $2.73^{\mathrm{a}}$ & 0.16 & $3.08^{\mathrm{ab}}$ & 0.70 & 3.15 & 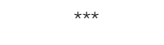 \\
\hline & El6. Animal welfare & $1.50^{\mathrm{a}}$ & 0.53 & $3.33^{\mathrm{C}}$ & 0.48 & $1.69^{a b}$ & 0.58 & $2.07^{b}$ & 0.64 & 2.15 & 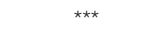 \\
\hline \multirow{3}{*}{ 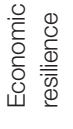 } & ER1. Investment & $1.20^{\mathrm{a}}$ & 0.62 & $3.29^{b}$ & 0.43 & $1.51^{\mathrm{a}}$ & 0.57 & $3.21^{b}$ & 0.93 & 2.30 & 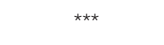 \\
\hline & ER2. Vulnerability & $1.60^{\mathrm{a}}$ & 0.37 & $2.05^{\mathrm{ab}}$ & 0.54 & $1.55^{\mathrm{a}}$ & 0.62 & $2.30^{\mathrm{b}}$ & 0.81 & 1.88 & $\star \star$ \\
\hline & ER3. Local economy & $2.21^{\mathrm{a}}$ & 0.46 & $2.92^{b}$ & 0.71 & $2.20^{\mathrm{a}}$ & 0.73 & $2.97^{b}$ & 0.57 & 2.58 & $\star \star$ \\
\hline \multirow{7}{*}{ 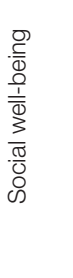 } & SW1. Decent livelihood & $2.58^{a}$ & 0.47 & $2.85^{\mathrm{ab}}$ & 0.54 & $3.23^{b}$ & 0.71 & $3.36^{b}$ & 0.61 & 3.01 & $\star \star$ \\
\hline & SW2. Fair trading practices & 0.50 & 0.38 & 0.52 & 0.07 & 0.52 & 0.17 & 0.51 & 0.14 & 0.51 & - \\
\hline & SW3. Labor rights & 2.13 & 0.54 & 2.00 & 0.80 & 1.60 & 0.41 & 1.65 & 0.49 & 1.85 & * \\
\hline & SW4. Equity & 3.80 & 0.74 & 3.38 & 1.03 & 2.97 & 0.75 & 3.48 & 0.69 & 3.41 & - \\
\hline & SW5. Human safety health & $3.64^{a}$ & 0.51 & $2.74^{\mathrm{b}}$ & 0.46 & $2.38^{b}$ & 0.87 & $2.67^{b}$ & 0.36 & 2.86 & 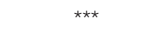 \\
\hline & SW6. Cultural diversity & 3.91 & 0.80 & 3.27 & 0.40 & 4.49 & 0.75 & 3.34 & 0.75 & 3.75 & - \\
\hline & Global sustainability indicator & 2.47 & & 2.84 & & 2.50 & & 2.65 & & 2.62 & - \\
\hline
\end{tabular}

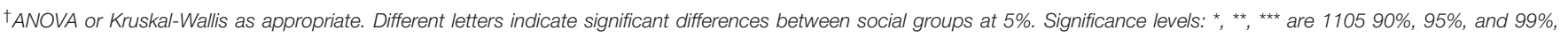
respectively.

(Rivera-Parra et al., 2020), which has caused time constraints for interaction with traditional production systems (Diantini et al., 2020). The following factors have also been registered: water contamination (Balseiro-Romero et al., 2018; Maurice et al., 2019), the presence of heavy metals in the food chain (Adzigbli and Yuewen, 2018; Maletić et al., 2019), including crops (Veil et al., 2004; Barraza et al., 2018) health risks for indigenous people and migrant settlers (Barraza et al., 2017; Merchán-Rivera and Chiogna, 2017), a loss of biodiversity (Durango-Cordero et al., 2018) and acculturation processes (Swing et al., 2012). The social and environmental history of the oil industries and stateowned companies in the Amazon basin (Becerra et al., 2018) have not been detrimental for the indigenous and migrant settler populations (Valdivia, 2007; Swing et al., 2012; Bebbington and Bury, 2013) due to the resulting economic dependence (Rival, 1992). This is similar to the scenario in Central Africa, where the Chad-Cameroon pipeline project did not improve the living conditions of the local indigenous community of Bagyeli, poverty increased and the quality of life decreased (Horta, 2007; Husar and Finka, 2016).

Although the production systems evaluated had high scores in most of the social issues, the lowest scores were in the Shuar's aja, mostly determined by fair trading practices and the sub-themes of responsible buyers, rights of suppliers, employee relations, forced labor, and child labor. This is not related to indigenous cultural dynamics, because the management of production systems, from a social perspective, is the result of a set of values, deeply rooted in the indigenous worldview (Goyes et al., 2021; Santafe-Troncoso and Loring, 2021; Varese, 2021), and ancestral knowledge is transmitted from generation to generation through harmonious relationships, based on solidarity and reciprocity (Sierra, 2000). These dynamics can also be identified in traditional production systems along the Napo riverbank, located to the north of the YBR (Heredia-R et al., 2020d,e). It is important to highlight that the contributions of indigenous and local knowledge in research are increasingly being considered in the science of sustainability (Mistry and Berardi, 2016; Tengö et al., 2017).

The discriminant analysis showed attributes of similarity (sustainability issues) between migrant settlers and the Shuar, corroborating the results of other researchers, who suggest that the Shuar are increasingly integrating into the market economy, participating in extensive cattle raising and commercial agriculture, and have similarly to migrant settlers (Rubenstein, 2001; Zimmerman et al., 2001; Rudel et al., 2002; Godoy et al., 2005; Gray et al., 2008). Meanwhile, greater divergence is evident among the Waorani and Kichwa in terms of sustainability, probably influenced by the following factors: (1) 
TABLE 8 | Spearman's correlation values between sustainability themes and social groups (Waorani, Shuar, Kichwa, and migrant settlers) in the Yasuní Biosphere Reserve, Amazon region of Ecuador.

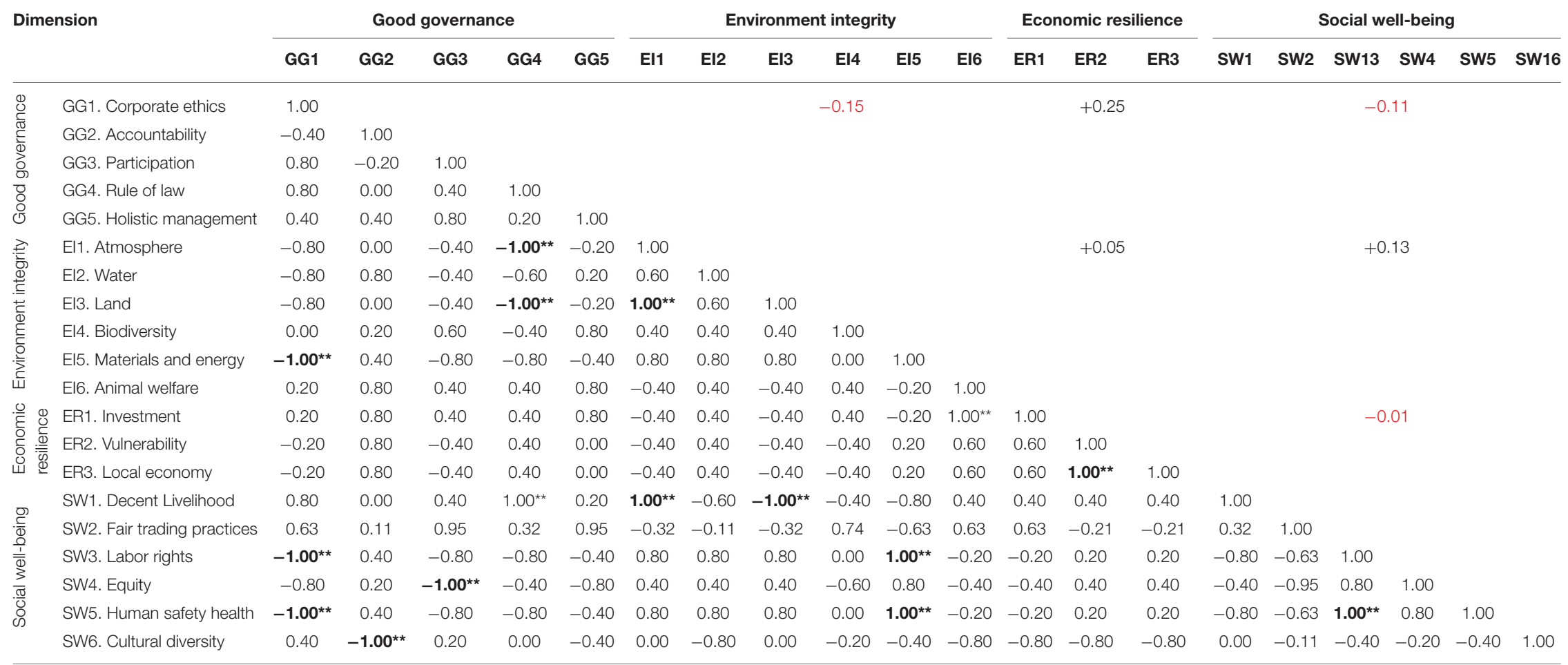

${ }^{*}$ Correlation is significant at 0.01 level. Trade-offs: results in red; and Synergies: results in bold. 


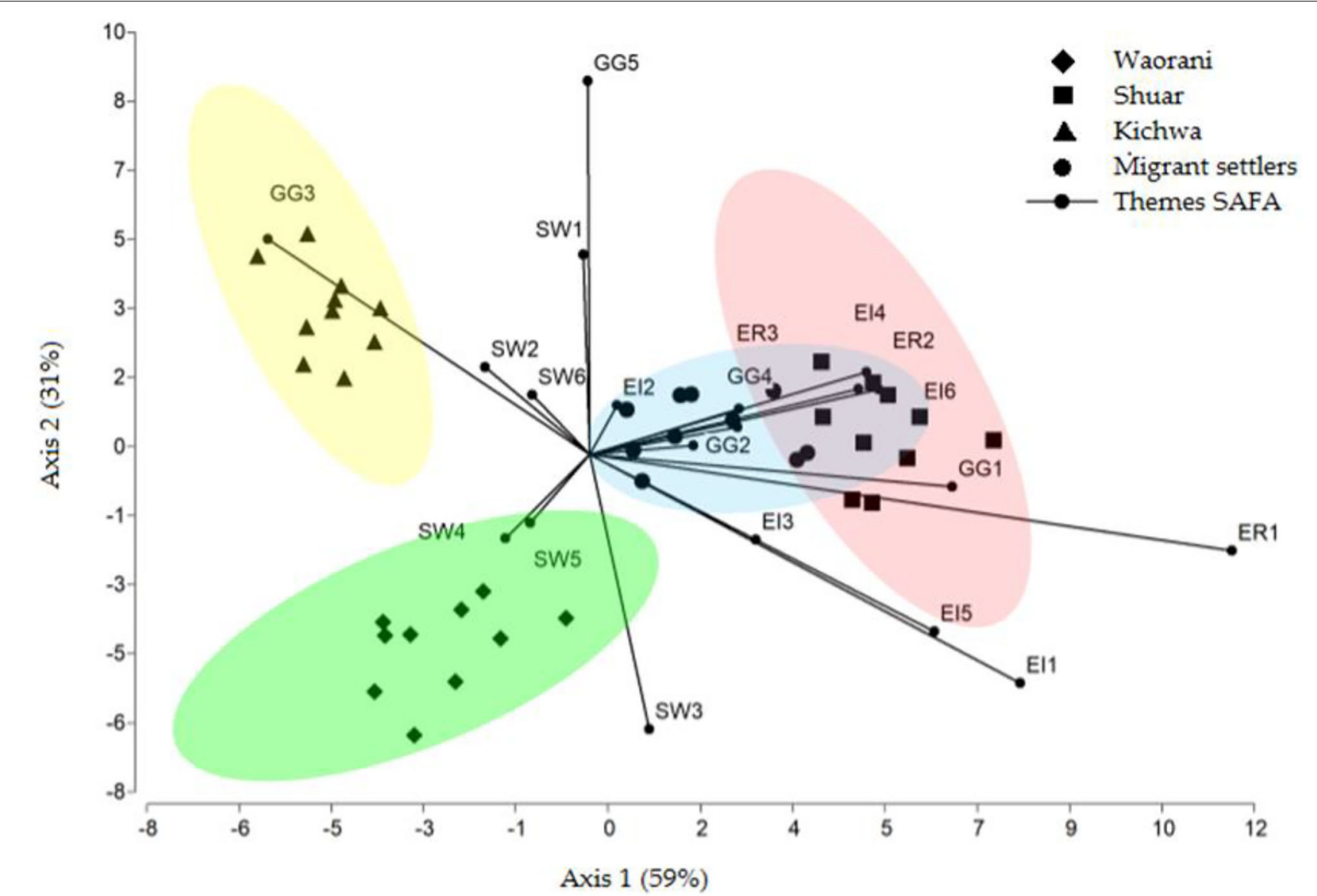

Themes: GG: Good governance; EI: Environmental integrity; ER: Economic resilience; SW: Social well-being

FIGURE 3 | Multivariate discriminant analysis between sustainability issues and social groups in the Yasuní Biosphere Reserve, Amazon region of Ecuador (Themes: GG, good governance; El, environmental integrity; ER, economic resilience; SW, social well-being).

Indigenous people adopt technologies for labor in traditional production systems (Sellers and Bilsborrow, 2020); (2) Oil activity (Rivera-Parra et al., 2020) has intensified, and this potentially represents a major transformation of their social, economic and environmental context (Codato et al., 2019), and to compound these changes, oil companies may offer access to employment, cash payments or health, and transportation services to indigenous communities in order to facilitate their work and/or comply with legal or internal "corporate social responsibility" mandates (O'Faircheallaigh, 2013; Billo, 2015); (3) The agricultural and extractive (hunting/fishing) frontier (Mena et al., 2017; Heredia-R and Hernández, 2019; Houssou et al., 2019) has advanced due to unsustainable agricultural activities (Heredia-R et al., 2020a,b,c), caused by a dependence on salaried jobs in the oil sector, according to the literature on the Dutch disease (Bozigar et al., 2016; Arsel et al., 2019; Erdogan et al., 2020), correlated with the majority of the EAR population being impoverished (Lang, 2017; Torres et al., 2017a), due to its externalities (Vasco et al., 2015). In addition, inequality in terms of sustainability in the groups evaluated is evidenced by the existence of new forms of land use and management, a greater use of land for planting cocoa, African palm species, and pastureland for cattle. These activities are completely linked to the global market, and also imply an increased use of chemicals and fertilizers, given the low quality of Amazonian soils and the quantity of pests. Therefore, modifications are occurring and even more intensely due to the presence of other actors, such as extractive companies and the State (Vasco et al., 2015; Salinas Castro et al., 2020).

\section{Synergies and Trade-Offs Within Sustainability Dimensions}

To be sustainable, a system must be robust, sufficiently productive, and use resources efficiently to achieve its equilibrium. However, there are often synergies or tradeoffs between the various goals of sustainability and their related objectives toward which sustainability is directed (NAS, 2010).

Greater synergies are observed between good governance dimension and economic resilience, as well as between environmental integrity and social well-being, which emphasizes the importance of good governance in influencing the level of 
performance in the other dimensions of sustainability (Schader et al., 2016) demonstrating the importance of the dimensions of sustainability in rural contexts and their influence on the strategic decision-making of indigenous populations and migrant settlers for the management of traditional production systems (Coteur et al., 2020). This implies that a specific focus on good governance can improve sustainability performance in traditional production systems through synergistic interactions with other sustainability dimensions. However, several studies show that trade-offs and synergistic relationships are dynamic and can change over time (Haase et al., 2012; Li et al., 2019), and vary across a wide range of conditions (Walker and Salt, 2012). Therefore, interactions that enhance sustainability should be prioritized according to the context and state of traditional production systems, while policies can facilitate the transition to more sustainable production systems.

\section{Policy Implications to Safeguard Traditional Agricultural Systems}

It is evident that the differences in terms of agricultural sustainability (Figure 2) between indigenous populations and migrant settlers (Figure 3) are narrowing (Rubenstein, 2001; Sellers and Bilsborrow, 2020). The existence of identified synergies and trade-offs (Table 8) provide policymakers with specific information to design sustainable development policies and rescue traditional agricultural systems in the DLZ.

Considering the global importance of the YBR and the Amazon basin in terms of conserving its high diversity, the findings of this research contribute to the management model developed for the communities that make up the DLZ in 2015. They were carried out by several national and local public organizations (MAGAP, 2016), who aimed to (a) strengthen governance in the DLZ; (b) achieve a balance between environmental conservation and living conditions; and (c) salvage cultural dynamics. The management model is implemented through a special regime that guarantees sustainability and minimizes risk factors for indigenous communities and migrant settlers in the DLZ (MAGAP, 2016).

At the national level, the Ecuadorian government has created different territorial management instruments that seek to restore degraded and deforested areas. Traditional agroforestry systems, such as the chakra, aja, kinkore, and agroforestry system, can contribute to the implementation of the Agenda for Productive Transformation in the Amazon (APTA) concerning its objective of bringing about a move toward more sustainable production systems (MAGAP, 2014). In this respect, it should also encourage the rescue of traditional systems that have been in use for millennia by the indigenous groups.

In terms of future research, based on our findings, we recommend studying the relationship between rural household livelihoods (livelihood strategies) (Torres et al., 2018) and forest ecosystems (forest governance) (Torres et al., 2013), as well as investigating biotrade alternatives in the DLZ-for livelihood strategies (Torres et al., 2017b; Boeri et al., 2020), climate change mitigation and the conservation of flora and fauna diversity-as a tool for biological corridors.

\section{CONCLUSIONS}

The differences in terms of sustainability between the traditional production systems evaluated are influenced by the sociodemographic conditions and characteristics, access routes, and extractive activities in the Amazon basin. This confirms the theory that differences between indigenous people and mixedrace settlers are narrowing, since there is greater similarity between the social, environmental, economic, and governing dynamics between the Shuar and migrant settler populations, while the sustainability weightings are farther apart between the Waorani and Kichwa populations.

Synergies exist between the dimensions of good governance and economic resilience among all groups assessed, following the finding of Schader et al. (2016), who emphasized the importance of good governance in influencing performance levels for other dimensions of sustainability. This implies that a specific focus on the good governance dimension can improve the sustainability performance of traditional production systems through its synergistic interactions with the other dimensions of sustainability. Thus, decision-makers at the local level and future research projects can intervene in the two trade-offs found between good governance and environment integrity, as well as good governance and social well-being, to contribute toward United Nations Sustainable Development Goals. The aim would be to optimize resources and time in the execution of plans, programs, and projects with the populations of the Amazon basin and at the same time verify if the same theory by Schader et al. (2016) works with the trade-off found between economic resilience and social well-being.

\section{DATA AVAILABILITY STATEMENT}

The original contributions presented in the study are included in the article/Supplementary Material, further inquiries can be directed to the corresponding author.

\section{ETHICS STATEMENT}

The studies involving human participants were reviewed and approved by Ethics Committee, Universidad Estatal Amazònica. Written informed consent for participation was not required for this study in accordance with the national legislation and the institutional requirements. Ethics clearance was also not required at Brock University due to use of secondary data (April 2021).

\section{AUTHOR CONTRIBUTIONS}

MH-R and DB performed the fieldwork. MH-R, BT, LP, and $\mathrm{LV}$ performed the statistical analyses. $\mathrm{MH}-\mathrm{R}, \mathrm{BT}, \mathrm{LV}$, and $\mathrm{CD}-\mathrm{A}$ wrote the first draft of the manuscript. All authors contributed to the conception and design of the study, revision of the manuscript, and reading and approval of the submitted version of the manuscript. 


\section{FUNDING}

The fieldwork of this research was carried out with small funds from the project: Analysis of sustainability and climate change in indigenous farmers and settlers of the Yasuní Biosphere Reserve, Ecuadorian Amazon of the Universidad Estatal Amazonica (Ecuador).

\section{ACKNOWLEDGMENTS}

We want to thank: the Autonomous Provincial Government of Orellana, the Apostolic Vicariate of Aguarico de Francisco de

\section{REFERENCES}

Adzigbli, L., and Yuewen, D. (2018). Assessing the impact of oil spills on marine organisms. J. Oceanogr. Mar. Res. 6:179. doi: 10.4172/2572-3103.1000179

Almeida, A., and Proaño, J. (2008). Tigre, Águila y Waorani, Una Sola Selva, Una Sola Lucha: Deuda Ecológica de las Transnacionales Petroleras con el Pueblo Waorani y el Parque Nacional Yasuní. Quito: Acción Ecológica.

Arsel, M., Pellegrini, L., and Mena, C. (2019). "Maria’s paradox: oil extraction and the misery of missing development alternatives in the Ecuadorian Amazon," in Immiserizing Growth: When Growth Fails the Poor, eds R. Kanbur, R. Sandbrook, and P. Shaffer (Oxford: Oxford University Press), 203-225. doi: 10.1093/oso/9780198832317.003.0009

Asimeh, M., Nooripoor, M., Azadi, H., Van Eetvelde, V., Sklenička, P., and Witlox, F. (2020). Agricultural land use sustainability in Southwest Iran: improving land leveling using consolidation plans. Land Use Policy 94:104555. doi: 10.1016/j.landusepol.2020.104555

Balseiro-Romero, M., Monterroso, C., and Casares, J. J. (2018). Environmental fate of petroleum hydrocarbons in soil: review of multiphase transport, mass transfer, and natural attenuation processes. Pedosphere 28, 833-847. doi: 10.1016/S1002-0160(18)60046-3

Barbieri, A. F., Bilsborrow, R. E., Mena, C. F., Pan, W., and Torres, B. (2003). "Changes in land cover and land use over time in the Ecuadorian Amazon," in 99th Meeting of the Association of American Geographers (New Orleans, LA).

Barbieri, A. F., and Carr, D. L. (2005). Gender-specific out-migration, deforestation and urbanization in the Ecuadorian Amazon. Glob. Planet. Change 47, 99-110. doi: 10.1016/j.gloplacha.2004.10.005

Barbieri, A. F., Carr, D. L., and Bilsborrow, R. E. (2009). Migration within the frontier: the second generation colonization in the Ecuadorian Amazon. Popul. Res. Policy Rev. 28, 291-320. doi: 10.1007/s11113-008-9100-y

Barraza, F., Maurice, L., Uzu, G., Becerra, S., López, F., Ochoa-Herrera, V., et al. (2018). Distribution, contents and health risk assessment of metal (loid) s in small-scale farms in the Ecuadorian Amazon: an insight into impacts of oil activities. Sci. Total Environ. 622, 106-120. doi: 10.1016/j.scitotenv.2017. 11.246

Barraza, F., Schreck, E., Lévêque, T., Uzu, G., López, F., Ruales, J., et al. (2017). Cadmium bioaccumulation and gastric bioaccessibility in cacao: a field study in areas impacted by oil activities in Ecuador. Environ. Pollut. 229, 950-963. doi: 10.1016/j.envpol.2017.07.080

Barrera-Roldán, A., and Saldívar-Valdés, A. (2002). Proposal and application of a Sustainable Development Index. Ecol. Indicat. 2, 251-256. doi: 10.1016/S1470-160X(02)00058-4

Bebbington, A., and Bury, J. (2013). Subterranean Struggles: New Dynamics of Mining, Oil, and Gas in Latin America, Vol. 8. New York, NY: University of Texas Press. doi: 10.7560/748620

Becerra, S., Maurice, L., and Desprats-Bologna, S. (2018). Nuestro vivir en la Amazonia ecuatoriana: entre la finca y el petroleo= Vivre en Amazonie équatorienne: entre pétrole et terres agricoles. Quito: Editorial Abya Yala. doi: 10.4000/books.irdeditions. 27431

Beckerman, S., Erickson, P. I., Yost, J., Regalado, J., Jaramillo, L., et al. (2009). Life histories, blood revenge, and reproductive success among
Orellana, the Decentralized Parish Autonomous Government of Dayuma and Inés Arango located in the Province of Orellana (Ecuador), and the Amazon State University (Ecuador) for their logistical support in the development of the research project and express our fraternal gratitude to indigenous farmers and migrant settlers for their collaboration.

\section{SUPPLEMENTARY MATERIAL}

The Supplementary Material for this article can be found online at: https://www.frontiersin.org/articles/10.3389/fsufs. 2021.782633/full\#supplementary-material the Waorani of Ecuador. Proc. Natl. Acad. Sci. U.S.A. 106, 8134-8139. doi: $10.1073 /$ pnas.0901431106

Belcher, K. W., Boehm, M. M., and Fulton, M. E. (2004). Agroecosystem sustainability: a system simulation model approach. Agric. Syst. 79, 225-241. doi: 10.1016/S0308-521X(03)00072-6

Bellon, M. R., Kotu, B. H., Azzarri, C., and Caracciolo, F. (2020). To diversify or not to diversify, that is the question. Pursuing agricultural development for smallholder farmers in marginal areas of Ghana. World Dev. 125:104682. doi: 10.1016/j.worlddev.2019.104682

Beristain, C. M., Páez Rovira, D., and Fernández, I. (2009). Las palabras de la selva: Estudio psicosocial del impacto de las explotaciones petroleras de Texaco en las comunidades amazónicas de Ecuador. Bilbao: HEGAO.

Billo, E. (2015). Sovereignty and subterranean resources: an institutional ethnography of Repsol's corporate social responsibility programs in Ecuador. Geoforum 59, 268-277. doi: 10.1016/j.geoforum.2014.11.021

Bilsborrow, R. E., Barbieri, A. F., and Pan, W. (2004). Changes in population and land use over time in the Ecuadorian Amazon. Acta Amazonica 34, 635-647. doi: 10.1590/S0044-59672004000400015

Boeri, P., Piñuel, L., Dalzotto, D., and Sharry, S. (2020). "Native biodiversity: a strategic resource to accelerate bioeconomy development in latin America and the Caribbean," in Agricultural, Forestry and Bioindustry Biotechnology and Biodiscovery, eds P. Chong, D. Newman, and D. Steinmacher (Cham: Springer), 163-174. doi: 10.1007/978-3-030-51358-0_10

Bond, A., Morrison-Saunders, A., and Pope, J. (2012). Sustainability assessment: the state of the art. Impact Assess. Project Appra. 30, 53-62. doi: 10.1080/14615517.2012.661974

Bonilla-Bedoya, S., Estrella-Bastidas, A., Molina, J. R., and Herrera, M. Á. (2018). Socioecological system and potential deforestation in Western Amazon forest landscapes. Sci. Total Environ. 644, 1044-1055 doi: 10.1016/j.scitotenv.2018.07.028

Boserup, E. (1965). The Conditions of Agricultural Growth: The Economics of Agrarian Change Under Population Pressure. New Brunswick, NJ: Transaction Publishers.

Bozigar, M., Gray, C. L., and Bilsborrow, R. E. (2016). Oil extraction and indigenous livelihoods in the Northern Ecuadorian Amazon. World Dev. 78, 125-135. doi: 10.1016/j.worlddev.2015.10.035

Broom, D. M., Galindo, F. A., and Murgueitio, E. (2013). Sustainable, efficient livestock production with high biodiversity and good welfare for animals. Proc. R. Soc. B 280, 2013-2025. doi: 10.1098/rspb.2013.2025

Caballero-Serrano, V., Alday, J. G., Amigo, J., Caballero, D., Carrasco, J. C., McLaren, B. E., et al. (2017). Social perceptions of biodiversity and ecosystem services in the Ecuadorian Amazon. Hum. Ecol. 45, 475-486. doi: 10.1007/s10745-017-9921-6

Cabodevilla, M. A. (2008). Zona intangible: ipeligro de muerte! Quito: CICAME, 206.

Campos, G., and Martínez, N. E. L. (2012). La observación, un método para el estudio de la realidad. Xihmai 7, 45-60. doi: 10.37646/xihmai.v7i13.202

Cañadas, V. B., and Sandoval, M. F. L. (2019). El trabajo femenino indígena en la economía agrícola familiar en la Amazonía del Ecuador. Espacio y Desarrollo 33, 67-89. doi: 10.18800/espacioydesarrollo.201901.004 
Carvajal, J., and Shacay, C. (2004). Aja Shuar, Sabiduría Amazónica. Macas: Fundación Etnoecológica y Cultura Tsantsa (FECTSA).

Cavendish, W. (2003). How Do Forest Support, Insure and Improve the Livelihoods of the Rural Poor? A Research Note. Bogor: CIFOR.

Codato, D., Pappalardo, S. E., Diantini, A., Ferrarese, F., Gianoli, F., and De Marchi, M. (2019). Oil production, biodiversity conservation and indigenous territories: towards geographical criteria for unburnable carbon areas in the Amazon rainforest. Appl. Geogr. 102, 28-38. doi: 10.1016/j.apgeog.2018.12.001

Colleoni, P., and Proaño, J. (2010). Camminantes en la selva. Los Pueblos en Aislamiento de la Amazonia Ecuatoriana. Informe 7 IWGIA. Grupo Internacional de Trabajo sobre Asuntos Indígenas (IWGIA) - 2010. p. 48. Available online at: http://www.iwgia.org/publicaciones/buscar-publicaciones? publication_id=275 (accessed January 20,2020).

Coq-Huelva, D., Higuchi, A., Alfalla-Luque, R., Burgos-Morán, R., and AriasGutiérrez, R. (2017). Co-evolution and bio-social construction: the Kichwa agroforestry systems (chakras) in the Ecuadorian Amazonia. Sustainability 9:1920. doi: 10.3390/su9101920

Coq-Huelva, D., Torres-Navarrete, B., and Bueno-Suárez, C. (2018). Indigenous worldviews and Western conventions: Sumak Kawsay and cocoa production in Ecuadorian Amazonia. Agric. Hum. Val. 35, 163-179. doi: 10.1007/s10460-017-9812-x

Coteur, I., Wustenberghs, H., Debruyne, L., Lauwers, L., and Marchand, F. (2020). How do current sustainability assessment tools support farmers' strategic decision making? Ecol. Indicat. 114:106298. doi: 10.1016/j.ecolind.2020.106298

Davis, A. P., Gole, T. W., Baena, S., and Moat, J. (2012). The impact of climate change on indigenous arabica coffee (Coffea arabica): predicting future trends and identifying priorities. PLOS ONE 7:e47981. doi: 10.1371/journal.pone.0047981

Davis, J., Sellers, S., Gray, C., and Bilsborrow, R. (2016). Indigenous migration dynamics in the Ecuadorian Amazon: a longitudinal and hierarchical analysis. J. Dev. Stud. 53, 1849-1864. doi: 10.1080/00220388.2016.1262028

De la Torre, S., and Cornejo, F. (2008). Saguinus tripartitus. IUCN 2008. IUCN Red List of Threatened Species. Available online at: http://www.iucnredlist.org (accessed December 14, 2020).

De Olde, E. M., Oudshoorn, F. W., Sørensen, C. A., Bokkers, E. A., and De Boer, I. J. (2016). Assessing sustainability at farm-level: Lessons learned from a comparison of tools in practice. Ecol. Indicat. 66, 391-404. doi: 10.1016/j.ecolind.2016.01.047

Di Rienzo, J. A., Casanoves, F., Balzarini, M. G., Gonzalez, L., and Robledo, M. T. C. W. (2011). InfoStat Versión 2011. Grupo InfoStat, FCA, Universidad Nacional de Córdoba, Argentina. Available online at: http://www.infostat.com. ar (accessed November 15, 2020).

Diantini, A., Pappalardo, S. E., Powers, T. E., Codato, D., Fera, G. D., Heredia-R, M., et al. (2020). Is this a real choice? Critical exploration of the social license to operate in the oil extraction context of the Ecuadorian Amazon. Sustainability 12:8416. doi: 10.3390/su12208416

Díaz-Reviriego, I., Fernández-Llamazares, A., Salpeteur, M., Howard, P., and Reyes-García, V. (2016). Gendered knowledge contributions to adaptive capacity and health sovereignty in Amazonia. Ambio 45, 263-275. doi: 10.1007/s13280-016-0826-1

Donders, I., and Barriocanal, C. (2020). The influence of markets on the nutrition transition of hunter-gatherers: lessons from the Western Amazon. Int. J. Environ. Res. Public Health 17:6307. doi: 10.3390/ijerph17176307

Dufour, D. (1990). Use of tropical rainforests by native amazonians. Bioscience 40, 652-659. doi: 10.2307/1311432

Durango-Cordero, J., Saqalli, M., Laplanche, C., Locquet, M., and Elger, A. (2018). Spatial analysis of accidental oil spills using heterogeneous data: a case study from the North-Eastern Ecuadorian Amazon. Sustainability 10:4719. doi: $10.3390 /$ su10124719

Erdogan, S., Yildirim, D. Ç., and Gedikli, A. (2020). Natural resource abundance, financial development and economic growth: an investigation on Next-11 countries. Resourc. Policy 65:101559. doi: 10.1016/j.resourpol.2019. 101559

Finer, M., Vijay, V., Ponce, F., Jenkins, C. N., and Kahn, T. R. (2009). Ecuador's Yasuni Biosphere Reserve: a brief modern history and conservation challenges. Environ. Res. Lett. 4:034005. doi: 10.1088/1748-9326/4/3/034005

Flores-Delgadillo, L., Fedick, S. L., Solleiro-Rebolledo, E., Palacios-Mayorga, S., Ortega-Larrocea, P., Sedov, S., et al. (2011). A sustainable system of a traditional precision agriculture in a Maya homegarden: soil quality aspects. Soil Tillage Res. 113, 112-120. doi: 10.1016/j.still.2011.03.001

Food and Agriculture Organization (2005). State of the World's Forests 2005. Rome: United Nations Food and Agricultural Organization.

Food and Agriculture Organization (2013). SAFA Sustainability Assessment of Food and Agriculture Systems. Roma: Indicators Food and Agriculture Organization of the United Nations, 271.

Food and Agriculture Organization (2014). SAFA: Sustainability Assessment of Food and Agriculture Systems: Tool User Manual Version 3.0. Roma: FAO Food and Agriculture Organization of the United Nations, 20.

Franzen, M., and James, E. (2007). Effect of market access on sharing practices within two Huaorani communities. Ecol. Econ. 63, 776-785. doi: 10.1016/j.ecolecon.2007.02.001

Galford, G. L., Soares-Filho, B., and Cerri, C. E. (2013). Prospects for land-use sustainability on the agricultural frontier of the Brazilian Amazon. Philosop. Trans. R. Soc. B Biol. Sci. 368:20120171. doi: 10.1098/rstb.2012.0171

Godoy, R., Reyes-Garcia, V., Huanta, T., Leonard, W., Vadez, V., Valdes-Galicia, C., et al. (2005). Why do subsistencelevel people join the market economy? Testing hypotheses of push and pull determinants in Bolivian Amazonia. J. Anthropol. Res. 61, 157-178. doi: 10.3998/jar.0521004.0061.202

González de Lema, S., and Herrera, I. E. (2017). La arquitectura shuar: ordenando el espacio mítico. Revista Española De Antropología Americana 47, 161-179. doi: 10.5209/REAA.61976

Goyes, D. R., South, N., Abaibira, M. A., Baicué, P., Cuchimba, A., and Ñeñetofe, D. T. R. (2021). Genocide and ecocide in four colombian indigenous communities: the erosion of a way of life and memory. Br. J. Criminol. 61, 965-984. doi: $10.1093 /$ bjc/azaa109

Gray, C., and Bilsborrow, R. (2020). Stability and change within indigenous land use in the Ecuadorian Amazon. Glob. Environ. Change 63:102116. doi: 10.1016/j.gloenvcha.2020.102116

Gray, C., Bilsborrow, R., Bremner, J., and Lu, F. (2008). Indigenous land use in the Ecuadorian Amazon: a cross-cultural and multilevel analysis. Hum. Ecol. 36, 97-109. doi: 10.1007/s10745-007-9141-6

Haase, D., Schwarz, N., Strohbach, M., Kroll, F., and Seppelt, R. (2012). Synergies, trade-offs, and losses of ecosystem services in urban regions: an integrated multiscale framework applied to the Leipzig-Halle Region, Germany. Ecol. Soc. 17:22. doi: 10.5751/ES-04853-170322

Henrich, J. (1997). Market incorporation, agricultural change and sustainability among the Machiguenga Indians of the Peruvian Amazon. Hum. Ecol. 25, 319-361. doi: 10.1023/A:1021982324396

Heredia-R, M., Bravo, C., Torres, B., and Alemán, R. (2020a). Innovación para el fortalecimiento de capacidades sobre sostenibilidad de los recursos naturales en poblaciones indígenas y mestizas-colonas: Reserva de Biosfera Yasuní. Orellana Revista Ibérica de Sistemas e Tecnologias de Informação, (E25), 103-116.

Heredia-R, M., Falconí, A. K., Barreto, D., Amores, K., Jamil, H., and Torres, B. (2020b). Conductas sustentables sobre el marco de evaluación SAFA-FAO: un aporte para poblaciones rurales vulnerables de la Amazonía. Revista Ibérica de Sistemas e Tecnologias de Informação, (E33), 312-326.

Heredia-R, M., Torres, B., Alemán, R., Bravo, C., and Hernández Díaz-Ambrona, C. (2020c). SAFA and GeoGebra Allies to evaluate natural and cultural sustainability: Yasuni Biosphere Reserve. Int. J. Adv. Sci. Eng. Inform. Technol. 10, 880-887. doi: 10.18517/ijaseit.10.2.10867

Heredia-R, M., Torres, B., Cayambe, J., Ramos, N., Luna, M., and Diaz-Ambrona, C. G. (2020d). Sustainability assessment of smallholder agroforestry indigenous farming in the amazon: a case study of Ecuadorian Kichwas. Agronomy 10:1973. doi: 10.3390/agronomy10121973

Heredia-R, M., Torres, B., Guerrero, E., Gallardo, D., Núñez, M., Alemán, R., et al. (2020e). Evaluación de la sostenibilidad de sistemas productivos en la franja de diversidad y vida: Reserva De Biosfera Yasuní, Amazonía. Revista Científica Axioma E33, 5-11.

Heredia-R, M. G., and Hernández, C. G. (2019). Comportamiento demográfico: dinámico - probabilístico de los pueblos indígenas en aislamiento de la Amazonía ecuatoriana. Revista Científica Axioma, 25-34. Available online at: http:// axioma.pucesi.edu.ec/index.php/axioma/article/view/557 (accessed January 02, 2020).

Herrera, J., Eguiguren, M. C., Cajas, F., Peñaherrera, P., and Ponce, M. (2017). "Proceso de dialogo en la F ranja de Diversidad y Vida el cantón Francisco de Orellana," in El último grito del Jaguar. Memorias del I Congreso sobre 
pueblos indígenas en aislamiento en la Amazonía ecuatoriana, ed En: Vallejo I y Ávila R (Instituto de Estudios Ecologistas del Tercer Mundo, Quito: Ediciones Abya-Yala) 343, 211-251.

Hill, R., Adem, Ç., Alangui, W. V., Molnár, Z., Aumeeruddy-Thomas, Y., Bridgewater, P., et al. (2020). Working with indigenous, local and scientific knowledge in assessments of nature and nature's linkages with people. Curr. Opin. Environ. Sustain. 43, 8-20. doi: 10.1016/j.cosust.2019.12.006

Hinde, P. R. A. (2001). Demographic methods. Population 56:478. doi: $10.2307 / 1534957$

Hoddinott, J. (2006). Shocks and their consequences across and within households in rural Zimbabwe. J. Dev. Stud. 42, 301-321. doi: 10.1080/00220380500405501

Holdsworth, C., Finney, N., Marshall, A., and Norman, P. (2013). Population and Society. London: Sage.

Holt, F. L., Bilsborrow, R. E., and Oña, A. I. (2004). Demography, Household Economics, and Land and Resource Use of Five Indigenous Populations in the Northern Ecuadorian Amazon: A Summary of Ethnographic Research. Occasional Paper, Carolina Population Center. Chapel Hill, NC: University of North Carolina, 87.

Horta, K. (2007). The Chad-Cameroon Oil and Pipeline Project. A Project Non-Completion Report: Environmental Defense, Centre for Environment and Development and Chadian Association for the Promotion and Defense of Human Rights. Available online at: http://relufa.org/partners/jhnewsletter/documents/ Aprojectnoncompletionreportapr07_eng.pdf (accessed December 11, 2020).

Houssou, N., Durango-Cordero, J., Bouadjio-Boulic, A., Morin, L., Maestripieri, N., et al. (2019). Synchronizing histories of exposure and demography: the construction of an agent-based model of the Ecuadorian Amazon colonization and exposure to oil pollution hazards. J. Artif. Soc. Soc. Simul. 22:1. doi: 10.18564 /jasss.3957

Hsu, A., and Zomer, A. (2014). "Environmental performance index," in Wiley StatsRef: Statistics Reference Online (New Haven, CT: Yale Center for Environmental Law and Policy), 1-5. doi: 10.1002/9781118445112.stat03789.pub2

Husar, M., and Finka, M. (2016). Local indigenous communities and oil industry. Der öffentliche Sektor 42.

Ima Omene, M. O. (2012). Saberes Waorani y Parque Nacional Yasuní: plantas, salud y bienestar en la Amazonía del Ecuador. Quito: Iniciativa Yasuní ITT, Ministerio Coordinador de Patrimonio, Ministerio del Ambiente.

IPBES (2012). Intergovernmental Platform on Biodiversity and Ecosystem Services United Nations Environment Program. Bonn.

Jadán, O., Günter, S., Torres, B., and Selesi, D. (2015). Riqueza y potencial maderable en sistemas agroforestales tradicionales como alternativa al uso del bosque nativo, Amazonia del Ecuador. Revista Forestal Mesoamericana Kurú 12, 13-22. doi: 10.18845/rfmk.v12i28.2096

Joiris, D. V. (2003). The framework of central African hunter-gatherers and neighbouring societies. Afr. Study Monogr. Suppl. 28, 57-79. doi: $10.14989 / 68426$

Jorgenson, J. P., and Coppolillo, P. (2001). "Trabajos de grupo: Grupo 1: Análisis de Amenazas," in Conservación y desarrollo sostenible del Parque Nacional Yasuní y su área de influencia, eds J. P. Jorgenson and M. C. Rodríguez (Quito: Ministerio del Ambiente/UNESCO/Wildlife Conservation Society), 194-211.

Kaivo-oja, J., Panula-Ontto, J., Vehmas, J., and Luukkanen, J. (2014). Relationships of the dimensions of sustainability as measured by the sustainable society index framework. Int. J. Sustain. Dev. World Ecol. 21, 39-45. doi: 10.1080/13504509.2013.860056

Karsten, R. A., Montano, M. C., Iglesias, G., and Dueñas, H. (2000). La vida y la cultura de los Shuar: cazadores de cabezas del Amazonas occidental: Quito la vida y la cultura de los Jíbaros del este del Quito:Ecuador.

Killeen, T. J., and Solórzano, L. A. (2008). Conservation strategies to mitigate impacts from climate change in Amazonia. Philosop. Trans. R. Soc. B Biol. Sci. 363, 1881-1888. doi: 10.1098/rstb.2007.0018

Knoke, T., Bendix, J., Pohle, P., Hamer, U., Hildebrandt, P., Roos, K., et al. (2014). Afforestation or intense pasturing improve the ecological and economic value of abandoned tropical farmlands. Nat. Commun. 5:5612. doi: $10.1038 /$ ncomms6612

Krause, T., and Ness, B. (2017). Energizing agroforestry: Ilex guayusa as an additional commodity to diversify Amazonian agroforestry systems. Int. J. Biodivers. Sci. Ecosyst. Serv. Manag. 13, 191-203. doi: $10.1080 / 21513732.2017 .1303646$
Kruskal, W. H., and Wallis, W. A. (1952). Use of ranks on onecriterion variance analysis. J. Am. Statist. Assoc. 47, 583-621. doi: 10.1080/01621459.1952.10483441

Lang, M. A. (2017). ¿Erradicar la pobreza o empobrecer las alternativas? Universidad Andina Simón Bolívar Ecuador. Quito: Ediciones Abya-Yala, 177.

Leclerc, C. (2012). Ladoption de l'agriculture chez les pygmées Baka du Cameroun; dynamique sociale et continuité structurale. Paris: FMSH édition.

Lemaire, G., Franzluebbers, A., de Faccio Carvalho, P. C., and Dedieu, B. (2014). Integrated crop-livestock systems: Strategies to achieve synergy between agricultural production and environmental quality. Agric. Ecosyst. Environ. 190, 4-8. doi: 10.1016/j.agee.2013.08.009

Lerner, A. M., Rudel, T. K., Schneider, L. C., McGroddy, M., Burbano, D. V., and Mena, C. F. (2014). The spontaneous emergence of silvopastoral landscapes in the Ecuadorian Amazon: patterns and processes. Region. Environ. Change 15, 1421-1431. doi: 10.1007/s10113-014-0699-4

Levang, P., Sitorus, S., and Dounias, E. (2007). City life in the midst of the forest: a Punan hunter-gatherers' vision of conservation and development. Ecol. Soc. 12:18. doi: 10.5751/ES-02036-120118

Li, Y., Westlund, H., and Liu, Y. (2019). Why some rural areas decline while some others not: An overview of rural evolution in the world. J. Rural Stud. 68, 135-143. doi: 10.1016/j.jrurstud.2019.03.003

Lopera-Marín, J. J., Angulo-Arizala, J., Murgueitio Restrepo, E., and MahechaLedesma, L. (2020). Producción de tubérculos y biomasa aérea del yacón, Smallanthus sonchifolius (Poepp.) H. Rob. (Asteraceae), para alimentación animal en el trópico alto colombiano. Livestock Research for Rural Development, 32. Available online at: http://www.lrrd.org/lrrd32/8/jjlop32135. html (accessed January 14, 2020).

Lovo, S., and Veronesi, M. (2019). Crop Diversification and Child Health: Empirical Evidence from Tanzania. Climate Change Adaptation. Berlin; Heidelberg: Springer, 1973-1994. doi: 10.1016/j.ecolecon.2019.01.005

Lu, F. (2007). Integration into the market among indigenous peoples: a crosscultural perspective from the Ecuadorian Amazon. Curr. Anthropol. 48, 593-602. doi: 10.1086/519806

Lu, F., and Bilsborrow, R. E. (2011). "A cross-cultural analysis of human impacts on the rainforest environment in Ecuador," in Human Population. Ecological Studies (Analysis and Synthesis), Vol. 214, eds R. Cincotta and L. Gorenflo (Berlin; Heidelberg: Springer), 127-151. doi: 10.1007/978-3-642-16707-2_8

Lu, F., Bilsborrow, R. E., and Oña, A. I. (2012). Modos de vivir y de sobrevivir: un estudio transcultural de cinco etnias en la Amazonia ecuatoriana. Quito: Abya-Yala.

Luzuriaga-Quichimbo, C. X., Hernández del Barco, M., Blanco-Salas, J., CerónMartínez, C. E., and Ruiz-Téllez, T. (2019). Plant biodiversity knowledge varies by gender in sustainable Amazonian agricultural systems called chacras. Sustainability 11:4211. doi: 10.3390/su11154211

MAE (2013). Programa para la Conservación y el Manejo Sostenible y sustentable del Patrimonio Natural y Cultural de la Reserva de la Biosfera Yasuní y sus pueblos en aislamiento. Ministerio del Ambiente.

MAGAP (2014). ATPA Proyecto Reconversión Agro productiva Sostenible de la Amazonia. MAGAP.

MAGAP (2016). Modelo de Gestión para el desarrollo de las 27 Comunidades de la Franja Diversidad y Vida del cantón Francisco de Orellana. Ministerio de Agricultura, Ganadería, Acuacultura y Pesca. Orellana, Ecuador, 39.

Maletić, S. P., Beljin, J. M., Rončević, S. D., Grgić, M. G., and Dalmacija, B. D. (2019). State of the art and future challenges for polycyclic aromatic hydrocarbons is sediments: sources, fate, bioavailability and remediation techniques. J. Hazard. Mater. 365, 467-482. doi: 10.1016/j.jhazmat.2018. 11.020

Maness, T., and Farrell, R. (2004). A multi-objective scenario evaluation model for sustainable forest management using criteria and indicators. Can. J. For. Res. 34, 2004-2017. doi: 10.1139/x04-075

Maurice, L., López, F., Becerra, S., Jamhoury, H., Le Menach, K., Dévier, M. H., et al. (2019). Drinking water quality in areas impacted by oil activities in Ecuador: associated health risks and social perception of human exposure. Sci. Total Environ. 690, 1203-1217. doi: 10.1016/j.scitotenv.2019.07.089

McCord, P. F., Cox, M., Schmitt-Harsh, M., and Evans, T. (2015). Crop diversification as a smallholder livelihood strategy within semi-arid agricultural systems near Mount Kenya. Land Use Policy 42, 738-750. doi: 10.1016/j.landusepol.2014.10.012 
Mena, C. F. (2007). Characterization and Modeling Agricultural and Forest Trajectories in the Northern Ecuadorian Amazon: Spatial Heterogeneity, Socioeconomic Drivers and Spatial Simulations. The University of North Carolina at Chapel Hill, New York, United states.

Mena, C. F., Bilsborrow, R. E., and McClain, M. E. (2006). Socioeconomic drivers of deforestation in the Northern Ecuadorian Amazon. Environ. Manage. 37, 802-815. doi: 10.1007/s00267-003-0230-Z

Mena, C. F., Laso, F., Martinez, P., and Sampedro, C. (2017). Modeling road building, deforestation and carbon emissions due deforestation in the Ecuadorian Amazon: the potential impact of oil frontier growth. J. Land Use Sci. 12, 477-492. doi: 10.1080/1747423X.2017.1404648

Mena, C. F., Walsh, S. J., Frizzelle, B. G., Xiaozheng, Y., and Malanson, G. P. (2011). Land use change on household farms in the Ecuadorian Amazon: design and implementation of an agent-based model. Appl. Geogr. 31, 210-222. doi: 10.1016/j.apgeog.2010.04.005

Merchán-Rivera, P., and Chiogna, G. (2017). Assessment of Contamination by Petroleum Hydrocarbons from Oil Exploration and Production Activities in Aguarico, Ecuador. Munich: Ecuador.

Michler, J. D., and Josephson, A. L. (2017). To specialize or diversify: agricultural diversity and poverty dynamics in Ethiopia. World Dev. 89, 214-226. doi: 10.1016/j.worlddev.2016.08.011

Mistry, J., and Berardi, A. (2016). Bridging indigenous and scientific knowledge. Science 352, 1274-1275. doi: 10.1126/science.aaf1160

Mittermeier, R. A., Myers, N., Thomsen, J. B., da Fonseca, G. A. B., and Olivieri, S. (1998). Biodiversity hotspots and major tropical wilderness areas: approaches to setting conservation priorities. Conserv. Biol. 12, 516-520. doi: 10.1046/j.1523-1739.1998.012003516.x

Mogues, T. (2011). Shocks and asset dynamics in Ethiopia. Econ. Dev. Cult. Change 60, 91-120. doi: 10.1086/661221

Monteros, I. (2011). Yasuní y redwoods: tala ilegal en bosques protegidos. Quito: Ecuador

Mullan, K., Sills, E., Pattanayak, S. K., and Caviglia-Harris, J. (2018). Converting forests to farms: the economic benefits of clearing forests in agricultural settlements in the Amazon. Environ. Resour. Econ. 71, 427-455. doi: 10.1007/s10640-017-0164-1

Murphy, L., Bilsborrow, R., and Pichón, F. (1997). Poverty and prosperity among migrant settlers in the Amazon rainforest frontier of Ecuador. J. Dev. Stud. 34, 35-65. doi: 10.1080/00220389708422511

Mustafa,M. A.,Mayes, S., andMassawe, F. (2019). "Crop diversification through a wider use of underutilised crops: a strategy to ensure food and nutrition security in the face of climate change," in Sustainable Solutions for Food Security, eds A. Sarkar, S. Sensarma, and G. Vanloon (Cham: Springer), 125-149. doi: 10.1007/978-3-319-77878-5_7

Myers, N. (1988). Threatened biotas: "hot spots" in tropical forests. Environmentalist 8, 187-208. doi: 10.1007/BF02240252

Myers, N., Mittermeier, R. A., Mittermeier, C. G., da Fonseca, G. A. B., and Kent, J. (2000). Biodiversity hotspots for conservation priorities. Nature 403, 853-858 doi: $10.1038 / 35002501$

NAS (2010). Toward Sustainable Agricultural Systems in the 21st Century. Washington, DC: The National Academies Press.

Ness, B., Urbel-Piirsalu, E., Anderberg, S., and Olsson, L. (2007). Categorizing tools for sustainability assessment. Ecol. Econ. 60, 498-508. doi: 10.1016/j.ecolecon.2006.07.023

O'Faircheallaigh, C. (2013). Extractive industries and Indigenous peoples: a changing dynamic? J. Rural Stud. 30, 20-30. doi: 10.1016/j.jrurstud.2012.11.003

Orta-Martínez, M., and Finer, M. (2010). Oil frontiers and indigenous resistance in the Peruvian Amazon. Ecol. Econ. 70, 207-218. doi: 10.1016/j.ecolecon.2010.04.022

Pan, W. K., and Bilsborrow, R. E. (2005). The use of a multilevel statistical model to analyze factors influencing land use: a study of the Ecuadorian Amazon. Glob. Planet. Change 47, 232-252. doi: 10.1016/j.gloplacha.2004.10.014

Paniagua Blanc, F. (2019). La frontera de la ira: La emocionalidad como marcador identitario entre los waorani de la Amazonía ecuatoriana (doctoral dissertation). Universidad Complutense de Madrid, Madrid, Spain. doi: 10.5209/reaa.71748

Pappalardo, S. E., De Marchi, M., and Ferrarese, F. (2013). Uncontacted waorani in the Yasuní Biosphere reserve: geographical validation of the Zona Intangible Tagaeri Taromenane (ZITT). PLoS ONE 8:e66293. doi: 10.1371/journal.pone.0066293

Pérez-Robalino, M. A., Pérez-Robalino, N. R., Fiallos-Ortega, E. V., WampankitJuank, N. M., and Cruz-Tobar, S. E. (2019). Sistemas de información geográfica en la parroquia Shuar Chiguaza, Morona Santiago. Una aproximación a la realidad actual. J. Selva Andina Biosphere 7, 3-17. doi: $10.36610 /$ j.jsab.2019.070100003

Perreault, T. (2005). Why chacras (swidden gardens) persist: agrobiodiversity, food security, and cultural identity in the Ecuadorian Amazon. Hum. Organ. 64, 327-339. doi: 10.17730/humo.64.4.e6tymmka388rmybt

Pichón, F. (1997). Colonist land-allocation decisions, land use, and deforestation in the Ecuadorian Amazon frontier. Econ. Dev. Cult. Change 45, 707-744. doi: $10.1086 / 452305$

Pitman, N. C. A. (2000). A large-scale inventory of two Amazonian tree communities (Ph.D. dissertation). Duke University, Durham, NC, Carolina.

Pitman, N. C. A., Terborgh, J. S., Silman, M. R., Nuñez, P., Neill, D. A., et al. (2002). A comparison of tree species diversity in two upper Amazonian forests. Ecology 83, 3210-3224. doi: 10.1890/0012-9658(2002)083[3210:ACOTSD]2.0.CO;2

Pohle, P., and Gerique, A. (2008). "Sustainable and non-sustainable use of natural resources by indigenous and local communities," in Gradients in a Tropical Mountain Ecosystem of Ecuador. Ecological Studies (Analysis and Synthesis), Vol. 198, eds E. Beck, J. Bendix, I. Kottke, F. Makeschin, and R. Mosandl (Berlin; Heidelberg: Springer), 331-345. doi: 10.1007/978-3-540-73526-7_32

Porro, R., Lopez-Feldman, A., Vela-Alvarado, J. W., Quiñonez-Ruíz, L., SeijasCardenas, Z. P., Vásquez-Macedo, M., et al. (2014). Forest use and agriculture in Ucayali, Peruvian Amazon: interactions among livelihood strategies, income and environmental outcomes. Tropics 23, 47-62. doi: 10.3759/tropics.23.47

Presidencia de la República de Ecuador (1999). Decreto Ejecutivo No. 552. Quito.

Presidencia de la República de Ecuador (2007). Decreto Ejecutivo No. (2187). Quito. Available online at: http://saveamericasforests.org/Yasuni/ News/ZonaIntangible/DECRETOZONA INTANGIBLE.pdf (accessed April 12, 2020).

Reyes-García, V., Paneque-Galvez, J., Bottazzi, P., Luz, A. C., Gueze, M., Macia, M. J., et al. (2014). Indigenous land reconfiguration and fragmented institutions: a historical political ecology of Tsimane' lands (Bolivian Amazon). J. Rural Stud. 34, 282-291. doi: 10.1016/j.jrurstud.2014.02.007

Reyes-García, V., Powell, B., Díaz-Reviriego, I., Fernández-Llamazares, Á., Gallois, S., and Gueze, M. (2019). Dietary transitions among three contemporary hunter-gatherers across the tropics. Food Secur. 11, 109-122. doi: 10.1007/s12571-018-0882-4

Rival, L. (1992). "Huaorani y Petróleo". En: Náufragos del Mar Verde. Quito: Abya Yala.

Rival, L. M. (2002). Trekking Through History: The Huaorani of Amazonian Ecuador. New York, NY: Columbia University Press. doi: 10.7312/riva11844

Rivera-Parra, J. L., Vizcarra, C., Mora, K., Mayorga, H., and Dueñas, J. C. (2020). Spatial distribution of oil spills in the north eastern Ecuadorian Amazon: a comprehensive review of possible threats. Biol. Conserv. 252:108820. doi: 10.1016/j.biocon.2020.108820

Rowland, D. (2004). Book review: demographic methods and concepts, Oxford: Oxford University Press, 2003, xiv + 546 pp. Eur. J. Popul. 20, 291-292. doi: 10.1007/s10680-004-4877-9

Rubenstein, S. (2001). Colonialism, the Shuar Federation, and the Ecuadorian state. Environ. Plan. D Soc. Space 19, 263-293. doi: 10.1068/d236t

Rudel, T. K., Bates, D., and Machinguiashi, R. (2002). Ecologically noble amerindians? cattle ranching and cash cropping among shuar and colonists in Ecuador. Latin Am. Res. Rev. 37, 144-159. Available online at: http://www.jstor. org/stable/2692107

SAFA (2012). Software SAFA Version 3.0. Evaluación de la sostenibilidad para la agricultura y la alimentación. Available online at: http://www.fao.org/nr/ sustainability/en/ (accessed May 4, 2020).

Salinas Castro, V., Bilsborrow, R. E., and Gray, C. (2020). Cambios socioeconómicos en el siglo XXI en poblaciones indígenas amazónicas: retos actuales. Estudios Demográficos y Urbanos 35, 83-116. doi: 10.24201/edu.v35i1.1768

Santafe-Troncoso, V., and Loring, P. A. (2021). Indigenous food sovereignty and tourism: the Chakra Route in the Amazon region of Ecuador. J. Sustain. Tour. 29:39. doi: 10.1080/09669582.2020.1770769 
Santos, G. F. (1996). "Introducción: hacia una antropología de lo contemporáneo en la Amazonía indígena," in F. Santos-Granero (Comp.), Globalización y cambio en la Amazonía indígena, Vol. 1 (Quito: Eucador), 7-43.

Schader, C., Baumgart, L., Landert, J., Muller, A., Ssebunya, B., Blockeel, J., et al. (2016). Using the Sustainability Monitoring and Assessment Routine (SMART) for the systematic analysis of trade-offs and synergies between sustainability dimensions and themes at farm level. Sustainability 8:274. doi: $10.3390 /$ su8030274

Schader, C., Grenz, J., Meier, M. S., and Stolze, M. (2014). Scope and precision of sustainability assessment approaches to food systems. Ecol. Soc. 19:42. doi: 10.5751/ES-06866-190342

Scheidel, A., Del Bene, D., Liu, J., Navas, G., Mingorría, S., Demaria, F., et al. (2020). Environmental conflicts and defenders: a global overview. Glob. Environ. Change 63:102104. doi: 10.1016/j.gloenvcha.2020.102104

Schwartzman, S., Moreira, A., and Nepstad, D. (2000). Rethinking tropical forest conservation: perils in parks. Conservat. Biol. 14, 1351-1357. doi: 10.1046/j.1523-1739.2000.99329.x

Sellers, S., and Bilsborrow, R. (2020). Agricultural technology adoption among migrant settlers and indigenous populations of the Northern Ecuadorian Amazon: are differences narrowing? J Land Use Sci. 14, 347-361. doi: 10.1080/1747423X.2020.1719225

Sellers, S., Bilsborrow, R., Salinas, V., and Mena, C. (2017). Population and development in the Amazon: a longitudinal study of migrant settlers in the Northern Ecuadorian Amazon. Acta amazonica 47, 321-330. doi: $10.1590 / 1809-4392201602663$

Sierra, R. (2000). Dynamics and patterns of deforestation in the western Amazon: the Napo deforestation front, 1986-1996. Appl. Geogr. 20, 1-16. doi: 10.1016/S0143-6228(99)00014-4

Sierra, R. (2004). A Spatial Analysis of the Ecological and Socioeconomic Outcomes of Agricultural Frontier Expansion in the Ecuadorian Amazon. Working Paper. Austin, TX: The University of Texas at Austin.

Sierra, R. (2013). Patrones y factores de deforestación en el Ecuador continental, 1990- 2010 y un acercamiento a los próximos 10 años. Quito: Conservación Internacional Ecuador y Forest Trends.

Sierra, R., Rodriguez, F., and Losos, E. (1999). Forest resource use change during early market integration in tropical rain forests: the Huaorani of upper Amazonia. Ecol. Econ. 30, 107-119. doi: 10.1016/S0921-8009(98)00101-3

Spearman, C. (1904). The proof and measurement of association between two things. Am. J. Psychol. 15, 72-101. doi: 10.2307/1412159

SPSS (2012). IBM Advanced Statistics 21. Available online at: http://www.sussex.ac. $\mathrm{uk} /$ its/pdfs/SPSS_Advanced_Statistics_21 (online)

Suárez, E., Morales, M., Cueva, R., Utreras, B. V., Zapata-Ríos, G., et al. (2009). Oil industry, wild meat trade and roads: indirect effects of oil extraction activities on a protected area in north-eastern Ecuador. Anim. Conserv. 12, 364-373. doi: $10.1111 / j .1469-1795.2009 .00262 . x$

Sutton, J., and Austin, Z. (2015). Qualitative research: data collection, analysis, and management. Can. J. Hosp. Pharmacy 68:226. doi: 10.4212/cjhp.v68i3.1456

Swing, K., Davidov, V., and Schwartz, B. (2012). Oil development on traditional lands of indigenous peoples: coinciding perceptions on two continents. J. Dev. Soc. 28, 257-280. doi: 10.1177/0169796X12448760

Taco, M. P. (2001). "El Parque Nacional Yasuní," in Conservación y desarrollo sostenible del Parque Nacional Yasuní y su área de influencia, eds J. P. Jorgenson and M. C. Rodríguez (Quito: Ministerio del Ambiente/UNESCO/Wildlife Conservation Society), 48-51

Tengö, M., Hill, R., Malmer, P., Raymond, C. M., Spierenburg, M., Danielsen, F., et al. (2017). Weaving knowledge systems in IPBES, CBD and beyondlessons learned for sustainability. Curr. Opin. Environ. Sustain. 26, 17-25. doi: 10.1016/j.cosust.2016.12.005

Tesfaye, W., and Tirivayi, N. (2020). Crop diversity, household welfare and consumption smoothing under risk: evidence from rural Uganda. World Dev. 125:104686. doi: 10.1016/j.worlddev.2019.104686

Thornton, P. K., and Herrero, M. (2001). Integrated crop-livestock simulation models for scenario analysis and impact assessment. Agric. Syst. 70, 581-602. doi: 10.1016/S0308-521X(01)00060-9

Tirira, D. G., Greeney, H. F., Omaca, C., Baihua, O., and Killackey, R. P. (2020). Species richness and ethnozoological annotations on mammals at the Boanamo indigenous community, Waorani territory, Orellana and Pastaza provinces, Ecuador. Mammalia 84, 535-551. doi: 10.1515/mammalia-20 19-0144

Torres, B., Günter, S., Acevedo-Cabra, R., and Knoke, T. (2018). Livelihood strategies, ethnicity and rural income: the case of migrant settlers and indigenous populations in the Ecuadorian Amazon. For. Policy Econ. 86, 22-34. doi: 10.1016/j.forpol.2017.10.011

Torres, B., Maza, O. J., Aguirre, P., Hinojosa, L., and Günter, S. (2015). "The contribution of traditional agroforestry to climate change adaptation in the Ecuadorian Amazon: the Chakra system," in Handbook of Climate Change Adaptation, ed W. L. Filho (Berlin; Heidelberg: Springer), 1973-1994. doi: 10.1007/978-3-642-38670-1_102

Torres, B., Radice, M., Ochoa-Moreno, S., and Cueva, K. (2017a). Primer seminario de economía de recursos naturales y biocomercio: oportunidades y desafíos. Puyo: Libro de memorias. Universidad Estatal Amazónica. Programa Economía de Recursos Naturales y Desarrollo Empresarial, 293.

Torres, B., Starnfeld, F., Vargas, J. C., Ramm, G., Chapalbay, R., Rios, M., et al. (2013). Gobernanza participativa en la Amazonía del Ecuador: recursos naturales y desarrollo sostenible. Puyo: Universidad Estatal Amazónica, Ministerio del Ambiente del Ecuador, Gobierno Autónomo Descentralizado Provincial de Napo y Cooperación Alemana al Desarrollo, 124.

Torres, B., Vargas, J. C., Arteaga, Y., Torres, A., and y Lozano, P. (2017b). Gente, Bosque y Biodiversidad: El rol del bosque sobre la biodiversidad y las poblaciones rurales. Puyo: Universidad Estatal Amazónica. Programa Economía de Recursos Naturales y Desarrollo Empresarial, 253.

Truong, L. D., Ho, N. N., Tran, D. T., and Nguyen, X. T. (2020). Does Cattle Production Contribute to Improving Welfare of Poor Ethnic Minority Households in Central Vietnam? Vol. 32, Livestock Research for Rural Development. Available online at: http://www.lrrd.org/lrrd32/10/thaok32161. html (accessed January 10, 2020).

United Nations (2009). Permanent Forum on Indigenous Issues, Report on the Eight Session. Economic and Social Council, Official Records Supplement No. 23 Available online at: http://www.un.org/esa/socdev/unpfii/documents/E_C_19_ 2009_14_en.pdf (accessed January 8, 2021).

Valdivia, G. (2007). The "Amazonian trial of the century": indigenous identities, transnational networks, and petroleum in Ecuador. Alternatives 32, 41-72. doi: 10.1177/030437540703200103

Valencia, R., Foster, R. B., Villa, G., Condit, R., Svenning, J., et al. (2004). Tree species distributions and local habitat variation in the Amazon: large forest plot in eastern Ecuador. J. Ecol. 92, 214-229. doi: 10.1111/j.0022-0477.2004.00876.x

Van Calker, K. J., Berentsen, P. B., Giesen, G. W., and Huirne, R. B. (2005). Identifying and ranking attributes that determine sustainability in Dutch dairy farming. Agric. Hum. Val. 22, 53-63. doi: 10.1007/s10460-004-7230-3

Vanclay, F., Baines, J. T., and Taylor, C. N. (2013). Principles for ethical research involving humans: ethical professional practice in impact assessment. Impact Assess. Proj. Appra. 31, 243-253. doi: 10.1080/14615517.2013.850307

Varese, S. (2021). "The indigenous politics of belonging: opposing neoliberal extractivism with ethical cosmologies," in Environment and Development, ed A. A. R. Loris (Cham: Palgrave Macmillan), 289-304. doi: 10.1007/978-3-030-55416-3_10

Vasco, C., Bilsborrow, R., and Torres, B. (2015). Income diversification of migrant colonists vs. indigenous populations: contrasting strategies in the Amazon. J. Rural Stud. 42, 1-10. doi: 10.1016/j.jrurstud.2015.09.003

Vasco, C., Bilsborrow, R., Torres, B., and Griess, V. (2018). Agricultural land use among mestizo colonist and indigenous populations: contrasting patterns in the Amazon. PLoS ONE 13:e0199518. doi: 10.1371/journal.pone.01 99518

Vasco, C., Tamayo, G., and Griess, V. (2017). The drivers of market integration among indigenous peoples: evidence from the Ecuadorian Amazon. Soc. Natural Resour. 30, 1212-1228. doi: 10.1080/08941920.2017.13 31487

Veil, J. A., Puder, M. G., Elcock, D., and Redweik, R. J. Jr. (2004). A White Paper Describing Produced Water from Production of Crude Oil, Natural Gas, and Coal Bed Methane (No. ANL/EA/RP-112631). New York, NY: Argonne National Lab. doi: $10.2172 / 821666$

Vera, V. R. R., Cota-Sánchez, J. H., and Grijalva Olmedo, J. E. (2017). Biodiversity, dynamics, and impact of chakras on the Ecuadorian Amazon. J. Plant Ecol. 12, 34-44. doi: 10.1093/jpe/rtx060 
Vera-Vélez, R., Grijalva, J., and Cota-Sánchez, J. H. (2019). Cocoa agroforestry and tree diversity in relation to past land use in the Northern Ecuadorian Amazon. New For. 50, 891-910. doi: 10.1007/s11056-019-09707-y

Viteri-Salazar, O., and Toledo, L. (2020). The expansion of the agricultural frontier in the northern Amazon region of Ecuador, 2000-2011: Process, causes, and impact. Land Use Policy 99:104986. doi: 10.1016/j.landusepol.2020. 104986

Waha, K., Van Wijk, M. T., Fritz, S., See, L., Thornton, P. K., Wichern, J., et al. (2018). Agricultural diversification as an important strategy for achieving food security in Africa. Glob. Change Biol. 24, 3390-3400. doi: 10.1111/gcb. 14158

Walker, B., and Salt, D. (2012). Resilience Thinking: Sustaining Ecosystems and People in a Changing World. Washington, DC: Island press.

Walsh, S. J., Messina, J. P., Mena, C. F., Malanson, G. P., and Page, P. H. (2008). Complexity theory, spatial simulation models, and land use dynamics in the Northern Ecuadorian Amazon. Geoforum 39, 867-878. doi: 10.1016/j.geoforum.2007. 02.011

Wasserstrom, R. (2010). "Roads, oil and native people: a controlled comparison on the Ecuadorian frontier," in Latin American Studies Association (LASA) Annual Meeting, Vol. 6 (Toronto, ON).

Wilson, T. (2016). Visualizing the demographic factors which shape population age structure. Demogr. Res. 35, 867-890. doi: 10.4054/DemRes.201 6.35 .29

Wunder, S. (2003). Oil Wealth and the Fate of the Forest. New York, NY: Routledge, 456.

Zhang, Y., Min, Q., Li, H., He, L., Zhang, C., and Yang, L. (2011). A conservation approach of globally important agricultural heritage systems
(GIAHS): improving traditional agricultural patterns and promoting scaleproduction. Sustainability 9:295. doi: 10.3390/su9020295

Zimmerman, B., Peres, C., and Malcolm, J. C. T. (2001). Conservation and development alliances with the Kayapó of south-eastern Amazonia, a tropical forest indigenous people. Environ. Conserv. 28, 10-22. doi: $10.1017 /$ S0376892901000029

Zurita-Benavides, M. G. (2017). Cultivando las plantas y la sociedad waorani. Bol. Mus. Para. Emílio Goeldi. Cienc. Hum. 12, 495-516. doi: 10.1590/1981.81222017000200013

Conflict of Interest: The authors declare that the research was conducted in the absence of any commercial or financial relationships that could be construed as a potential conflict of interest.

Publisher's Note: All claims expressed in this article are solely those of the authors and do not necessarily represent those of their affiliated organizations, or those of the publisher, the editors and the reviewers. Any product that may be evaluated in this article, or claim that may be made by its manufacturer, is not guaranteed or endorsed by the publisher.

Copyright $\odot 2022$ Heredia-R, Torres, Vasseur, Puhl, Barreto and Díaz-Ambrona. This is an open-access article distributed under the terms of the Creative Commons Attribution License (CC BY). The use, distribution or reproduction in other forums is permitted, provided the original author(s) and the copyright owner(s) are credited and that the original publication in this journal is cited, in accordance with accepted academic practice. No use, distribution or reproduction is permitted which does not comply with these terms. 